\title{
The geochemistry of gem opals as evidence of their origin
}

\author{
Eloïse Gaillou, ${ }^{\mathrm{a}, \mathrm{b}^{*}}$, Aurélien Delaunay ${ }^{\mathrm{a}}$, Benjamin Rondeau ${ }^{\mathrm{c}}$, Martine Bouhnik- \\ le-Coz ${ }^{\mathrm{d}}$, Emmanuel Fritsch $^{\mathrm{a}}$, Guy Cornen ${ }^{\mathrm{c}}$, Christophe Monnier ${ }^{\mathrm{c}}$
}

${ }^{a}$ Université de Nantes, Nantes Atlantique Universités, CNRS, Institut des Matériaux Jean Rouxel (I.M.N.), UMR 6502, 2 rue de la Houssinière, B.P. 32229, Nantes, F-44000 France.

${ }^{b}$ Department of Mineral Sciences, Smithsonian Institution, Washington, DC 20560, USA.

${ }^{c}$ Université de Nantes, Nantes Atlantique Universités, Laboratoire de Planétologie et Géodynamique, U.F.R. des Sciences et des Techniques, 2 rue de la Houssinière, B.P. 92208, Nantes, F-44322, France

${ }^{d}$ Laboratoire de Géochimie, Bâtiment 14B C.A.R.E.N. Géoscience Rennes, av. du Gl Leclerc, F-35042 Rennes, France

Received 15 September 2006; accepted 14 July 2007

\begin{abstract}
Seventy-seven gem opals from ten countries were analyzed by inductively coupled plasma-mass spectrometry (ICP-MS) through a dilution process, in order to establish the nature of the impurities. The results are correlated to the mode of formation and physical properties and are instrumental in establishing the geographical origin of a gem opal. The geochemistry of an opal is shown to be dependant mostly on the host rock, at least for examples from Mexico and Brazil, even if modified by weathering processes. In order of decreasing concentration, the main impurities present are Al, $\mathrm{Ca}, \mathrm{Fe}, \mathrm{K}, \mathrm{Na}$, and $\mathrm{Mg}$ (more than $500 \mathrm{ppm}$ ). Other noticeable elements in lesser amounts are $\mathrm{Ba}$, followed by $\mathrm{Zr}, \mathrm{Sr}, \mathrm{Rb}, \mathrm{U}$, and $\mathrm{Pb}$. For the first time, geochemistry helps to discriminate some
\end{abstract}

\footnotetext{
* Corresponding author: Eloise.Gaillou@cnrs-imn.fr; asteriee@yahoo.fr
} 
varieties of opals. The Ba content, as well as the chondrite-normalized REE pattern, are the keys to separating sedimentary opals $(\mathrm{Ba}>110 \mathrm{ppm}, \mathrm{Eu}$ and $\mathrm{Ce}$ anomalies) from volcanic opals $(\mathrm{Ba}<110$ ppm, no Eu or $\mathrm{Ce}$ anomaly). The $\mathrm{Ca}$ content, and to a lesser extent that of $\mathrm{Mg}, \mathrm{Al}, \mathrm{K}$ and $\mathrm{Nb}$, helps to distinguish gem opals from different volcanic environments. The limited range of concentrations for all elements in precious (play-of-color) compared to common opals, indicates that this variety must have very specific, or more restricted, conditions of formation. We tentatively interpreted the presence of impurities in terms of crystallochemistry, even if opal is a poorly crystallized or amorphous material. The main replacement is the substitution of $\mathrm{Si}^{4+}$ by $\mathrm{Al}^{3+}$ and $\mathrm{Fe}^{3+}$. The induced charge imbalance is compensated chiefly by $\mathrm{Ca}^{2+}, \mathrm{Mg}^{2+}, \mathrm{Mn}^{2+}, \mathrm{Ba}^{2+}, \mathrm{K}^{+}$, and $\mathrm{Na}^{+}$. In terms of origin of color, greater concentrations of iron induce darker colors (from yellow to "chocolate brown"). This element inhibits luminescence for concentrations above 1,000 ppm, whereas already a low content in $\mathrm{U}(\leq 1 \mathrm{ppm})$ induces a green luminescence.

Keywords: opal, chemical composition, trace-element analysis, genesis, ICP-MS

\section{Introduction}

Opal is an amorphous (opal-A) or poorly crystalline (opal-CT) hydrated silica, $\mathrm{SiO}_{2} \cdot \mathrm{nH}_{2} \mathrm{O}$ (Jones and Segnit, 1971). The mode of formation of gem opal has been the subject of much speculation. Surprisingly, only a few detailed geochemical analyses have been conducted, mainly on Australian material (Bartoli et al., 1990; McOrist et al., 1994; McOrist and Smallwood, 1995, 1997). Furthermore, those analyses were performed only on opal-A, and not on opal-CT which are more widely distributed around the world.

The main objective of this study is to understand the mode of formation of gem opals on the basis of their trace element chemistry. Secondly, the gemological objective is to identify the 
geographic and geologic origin of such gems. Sellers want to know where gems come from as some localities are more valuable than others (for example, fire opal from Mexico is better known, and hence more valued, than any other fire opal in the world), and depending on this, some gems are thus easier to sell. The knowledge of the geographical origin is also useful for archaeometry, to study ancient routes of gem trade (i.e., Giuliani et al., 2000). Finally, we consider the influence of geochemistry on some physical properties such as color or luminescence. With this goal in mind, 77 opals from 10 different countries were characterized (using laser Raman spectroscopy, scanning electron microscopy and luminescence spectroscopy), then analyzed for their trace elements using inductively coupled plasma-mass spectrometry (ICP-MS). The host rocks from Mexico and Brazil were also analyzed (ICP-MS, ICP Atomic Emission Spectrometry) in order to understand the mobilization of elements during opal deposition.

\section{Background}

Several classifications of opal are useful for our purposes. The first is based on its appearance: precious ("play-of-color" or "noble") opals are more valuable than "common" opals, which do not display this optical phenomenon. The play-of-color is due to diffraction of visible light on a perfect network of silica spheres having the adequate diameter, between 150 and $300 \mathrm{~nm}$ (see e.g., Sanders, 1964). Common opals can still be very valuable as gems for their transparency and their body color which spans a large spectrum. Another classification is based on X-ray diffraction (Jones and Segnit, 1971), and depends on opal "crystallinity". It distinguished three varieties of opals: opal-A for amorphous, opal-CT for disordered $\alpha$-cristobalite with $\alpha$-tridymitic stacking, and opal-C for $\alpha$ cristobalite (with only a small amount of $\alpha$-tridymite). Elzea and Rice (1996) postulated that opals$\mathrm{CT}$ and $-\mathrm{C}$ form a continuous series. This is why we chose to restrict our notation in this study to opal-A and opal-CT, abandoning the term opal-C. At present, the distinction between these two 
varieties can be done non-destructively with Raman spectroscopy (Ostrooumov et al., 1999).

Opal forms either in volcanic or sedimentary deposits. It is believed to come from the weathering of silicic rocks (rhyolite or sandstones for example), followed by precipitation from a $\mathrm{SiO}_{2}$-enriched liquid in cavities (e.g., Des Cloizeaux, 1862; Lacroix, 1896; Gübelin, 1986; Koivula et al., 1983; Payette, 1999; Smallwood, 1999; Horton, 2002). Opal is not a pure form of silica as it contains water as a component, and some impurities and trace elements can also enter its structure. The most common impurity is aluminum, which substitutes for silicon (Bartoli et al., 1990). Australian opals are the best studied (Bayliss and Males, 1965; McOrist et al., 1994; McOrist and Smallwood, 1995, 1997), probably because they represent $95 \%$ of world production (e.g., Horton, 2002; Pewkliang et al., 2004). Some other opals have been analyzed semi-quantitatively, e.g., from Opal Butte, Oregon, USA (Holzhey, 1997) and Brazil (Bartoli et al., 1990). From these data, one can establish that “impurities" (i.e., elements present at concentrations above $500 \mathrm{ppm}$ ) are $\mathrm{Al}, \mathrm{Ca}, \mathrm{K}, \mathrm{Mg}, \mathrm{Fe}$ and $\mathrm{Na}$. Elements at concentrations below 500 ppm are named "trace elements". These are mainly $\mathrm{Ba}, \mathrm{Sr}$, $\mathrm{Rb}, \mathrm{Mn}, \mathrm{Ti}$, and sometimes $\mathrm{U}$ or $\mathrm{Nb}$ (the latter is typical of Somali and Ethiopian opals; Johnson et al., 1996; Kinnaird and Jackson, 2000). In some deposits, the U concentration in opals is high enough (around $100 \mathrm{ppm}$ ) to determine ages of alteration, as in the Virgin Valley or Yucca Mountain, Nevada deposits (Zielinski, 1982; Neymark et al., 2000).

The influence of trace element chemistry on the physical properties of opal such as color or luminescence has been partially studied. The body color of opal is usually due to colored mineral inclusions (e.g., Fritsch et al., 1999). Not all opals are fluorescent, and two types of luminescence have been recognized. The first has a green color, is attributed to uranyl groups (Fritsch et al., 2001, 2003) and is believed to be typical of common opals. The second is reportedly induced by intrinsic oxygen-related defects typical of amorphous silica structure. These defects may be non-bridging oxygen (NBO), which are localized on the internal surface of such materials (Fritsch et al., 2001, 
2003). This blue luminescence is well known for opals from the Great Artesian Basin in Australia where it is utilized to find opals during prospecting, as it is believed to be typical of precious opals (e.g., Smallwood, 1999).

Some authors attempted to establish geochemical differences between opals of different color, paleness, and between precious and common opals (McOrist et al., 1994; McOrist and Smallwood, 1995, 1997). They noticed that green, blue and pink opals have a higher concentration in several trace elements than other opals (e.g., $\mathrm{Mg}$ and $\mathrm{Cu}$ for green and blue opals, $\mathrm{Mg}$ and $\mathrm{Al}$ for pink opals). They also found that no particular element was characteristic of a specific deposit and, typically, precious opals contain fewer impurities than common opals.

\section{Materials and methods}

\subsection{Materials}

Our sampling covered most commercial gem opal localities worldwide, not only the commonly studied Australian sources. The samples are listed in Table 1, along with their principal characteristics: geographical origin, appearance and Raman type. Some samples from Australia were analyzed for comparison with previous work (10 samples). Mexico, being the second largest world producer because of its large number of deposits all over the country, is widely represented in this study with 32 samples coming from 11 deposits in 4 states. Most of these opals were sampled in the field during four trips to the Mexican high plateaus. Other samples come from Ethiopia (8 samples), Honduras (7), Brazil (6), USA (4), Kazakhstan (3), Slovakia (3), Peru (2) and Tanzania (2). Samples are all gem, common or precious opals, opal-A or opal-CT and come from volcanic or sedimentary environments. Their body color spans almost the entire visible spectrum: blue, green, 
yellow, orange, red, pink, white, brown, grey and black, and they are transparent to opaque. Table 1 lists the samples identifying characteristics.

In order to characterize opal formation and mobilization of elements, some analyses were also performed on 10 host rocks, listed in Table 2. Host rocks of Mexican gem opals were collected in the field together with opals, and 9 were analyzed. One host rock of gem opal from Piaui, Pedro II mine, Brazil, was donated and analyzed. Unfortunately, wholesalers do not commonly sell opal host rocks, thus limiting our sampling. Analyses were done on both the host rock and opal coming from this rock, or sometimes on opal coming from the same deposit (three samples).

\subsection{Methods}

\subsubsection{Determination of gemological properties}

In order to verify that our samples were indeed opals, a refractometer of Russian manufacture was used to measure the refractive index (RI) with an optical contact liquid of 1.79 RI. The specific gravity was measured by the hydrostatic method. Ultraviolet (UV) photoluminescence was observed using an A. Krüss UV 240 shortwave (254 nm) and longwave (365 nm) 4W UV lamp.

The mineralogical classification of opal-A versus -CT was done using a Bruker RFS 100 Fourier transform Raman spectrometer. To duplicate conditions used by Ostrooumov et al. (1999) and Smallwood et al. (1997), 1000 scans were accumulated at a power of $350 \mathrm{~mW}$ and a resolution of $4 \mathrm{~cm}^{-1}$. The Nd YAG laser used for excitation has a wavelength of $1064 \mathrm{~nm}$, preventing most luminescence.

\subsubsection{Chemical analyses}

Opal trace element concentrations were determined by ICP-MS using an Agilent Technologies 
HP4500 at Rennes University, France. Normal plasma conditions were used, with the instrumental parameters listed in Table 3 and the procedure followed that of Bouhnik-le-Coz et al. (2001). Each decontaminated sample (between 50 and $300 \mathrm{mg}$ in size) was digested in a screw-top Teflon bomb (15 mL- Savillex ${ }^{\circledR}$ USA) by treatments using hydrofluoric (HF $29 \mathrm{~N}$ sub-boiling grade) and nitric acid (14N sub-boiling grade). The sample was dissolved in HF and evaporated to dryness. The last three treatments with nitric acid were necessary to eliminate the HF excess. Quantitative analyses were performed using a conventional external calibration procedure. Three external standard solutions were prepared from multi-element and mono-element standards (certified solutions, AccuStandard, USA). The international geostandards SLRS-4 (riverine water reference material for trace metals certified by the National Research Council of Canada, see Yeghicheyan et al., 2002) and BHVO (basalt rock reference material) were used to check the validity and reproducibility of the analyses by ICP-MS. Indium was added as an internal standard at a concentration level of $100 \mathrm{ppb}$. The calibration curves were calculated from the intensity ratios of the internal standard and the analyzed elements. Detection limits presented in Table 4 were expressed from the threefold standard deviations of the blank intensities (B) and the intensities of $10 \mathrm{ppb}$ multi-element standard solution (S) using the following equation: $\mathrm{LD}(\mathrm{ppb})=3 \sigma \times 10(\mathrm{ppb}) /(\mathrm{S}-\mathrm{B})$.

It must be noted that $\mathrm{Ti}, \mathrm{Zr}, \mathrm{V}, \mathrm{Nb}, \mathrm{As}$ and $\mathrm{P}$ were not certified for reference standards. $\mathrm{We}$ also tried to use the laser ablation process (LA-ICP-MS), which consumes much less material and is a key towards non-destructive measurements, but we encountered technical difficulties: it was impossible to focus the laser on some samples, especially colorless transparent ones.

Trace element compositions of whole rock samples were measured on a VG Plasma Quad 2+ ICP-MS, using purified lithium tetraborate fusion of rock powder. The internal standard solution (Ge, Mo, Rh, Re and Bi at $10 \mathrm{ppb}$ each) and external geostandards (BR and BHVO) were used for instrument calibration. 
Major element compositions of whole rock samples were measured on a ULTIMA C Jobin-Yvon ICP-AES, using purified lithium tetraborate fusion of rock powder. The ICP-AES analytical conditions are given in Cantagrel and Pin (1994) and international rock standards (BHVO, BR, GH and DRN) were used for instrument calibration. Both trace and major elements were analyzed at the Laboratoire Magmas et Volcans (LMV) in Clermont-Ferrand, France.

\section{Results}

\subsection{Main features of opal trace element chemistry}

The impurities in opal are, in order of decreasing average concentration, $\mathrm{Al}$ (around 4,500-5,000 ppm) then $\mathrm{K}, \mathrm{Fe}$ and $\mathrm{Ca}$ (about 1,000 ppm) and finally $\mathrm{Na}$ and $\mathrm{Mg}$ (around $500 \mathrm{ppm}$; for all data, see Table 4). Among the most important trace elements are, in order of decreasing concentration, $\mathrm{Ba}, \mathrm{Zr}$ (not standardized), $\mathrm{Sr}, \mathrm{Rb}, \mathrm{Mn}, \mathrm{Zn}, \mathrm{Y}, \mathrm{Pb}$ and $\mathrm{Cu}$. Such impurities are overall typical of silicates; the concentrations of some of these ( $\mathrm{U}, \mathrm{Pb}, \mathrm{Ba}$ are considered incompatible) may vary widely in most silicate minerals.

Despite the absence of stoichiometry and of a well-defined crystallographic structure, relations of substitution and proportionality exist between some elements in opals. These relations provide some information on the pseudo-crystallochemistry of this poorly crystallized to amorphous material and on the affinities between elements. Silicon atoms can be substituted by aluminum or iron atoms (Webb et al., 1987; Bartoli et al., 1983, 1990). The replacement of $\mathrm{Si}^{4+}$ by $\mathrm{Al}^{3+}$ or $\mathrm{Fe}^{3+}$ induces a charge imbalance, which must be compensated by the contribution of divalent or monovalent cations ( such as $\mathrm{Na}^{+}, \mathrm{Ca}^{2+}, \mathrm{K}^{+}, \mathrm{Ba}^{2+}, \mathrm{Mg}^{2+}$ ). There is, therefore, a correlation between 
$(\mathrm{Al}+\mathrm{Fe})$ and the sum of the most common divalent and monovalent cations in opal (Fig. 1). The relation of substitution is formalized in equation. 1:

$$
8\left(\mathrm{Al}^{3+}+\mathrm{Fe}^{3+}\right)+6\left(\mathrm{Ca}^{2+}+\mathrm{Mg}^{2+}+\mathrm{Mn}^{2+}+\mathrm{Ba}^{2+}+\mathrm{K}^{+}+\mathrm{Na}^{+}\right)=27 \mathrm{Si}^{4+}
$$

The coefficient of the correlation line between $\mathrm{Al}, \mathrm{Fe}$ and $\mathrm{Ca}, \mathrm{Mg}, \mathrm{K}, \mathrm{Na}, \mathrm{Mn}, \mathrm{Ba}$ as seen on Fig. 1 is $0.75(6 / 8)$, which is exactly that determined from equation 1 . Note that opal from Mapimi (Mexico) and Peru are absent from this figure, because they contain extra phases as inclusions (palygorskite) and thus the equation would be meaningless. Four samples plot below the correlation line (Fig. 1), as do two others with particularly high Fe concentration (from Mexico), not shown in this figure. Some elements are of course missing from the equation. $\mathrm{H}^{+}$, for example, was not analyzed for. Another possibility is that $\mathrm{Al}$ and Fe are in excess in these opals because of some inclusions (for example inclusion of some phyllosilicates - we will show subsequently that such an association is possible); it is probably the case of the four Fe-rich opals from Mexico.

If substitution does exist, elements may also be incorporated in other ways. For example, Fe may be in the form of oxide or hydroxide at a nanometric scale in the body of the opal. Bivalent and monovalent cations may be incorporated either in the whole mass or on the surface of nanograins, which are the elementary block of at least opal-CT (Fritsch et al., 2002).

\subsection{Opal colored by other phases}

The body color of opals (when it could be established) has so far always been linked to inclusions (Louis et al., 1968; Bojar and Taucher, 1994, 1995; Fritsch et al., 1999, 2004). Pink opals from Mexico (Durango state, Mapimi area) and Peru (Acari area) are known to contain palygorskite, a phyllosilicate with the chemical formula $(\mathrm{Mg}, \mathrm{Al})_{2} \mathrm{Si}_{4} \mathrm{O}_{10}(\mathrm{OH}) \cdot 4\left(\mathrm{H}_{2} \mathrm{O}\right)$, as inclusions (Fritsch et al., 2004). These authors estimated from specific gravity measurements that the 
palygorskite content in pink opals is about $29 \%$ for Mapimi and about $38 \%$ for Peru. From our measurements of $\mathrm{Al}$ and $\mathrm{Mg}$ concentrations, we can estimate a proportion of palygorskite in these opals that is $25 \%$ palygorskite in material from Mapimi and $40 \%$ in stones from Peru. These are consistent with previous work. Assuming that the palygorskite content is typical of each locality, its measurement is therefore a clue for determining the geographical origin of a pink opal.

A white opal from Mapimi has been analyzed (sample no 267). This opal also contains palygorskite as an inclusion, with a calculated concentration of $8.7 \%$. This confirms that the pink color is not due to the inclusion of palygorskite alone, but to an organic substance which belongs to the quinone family, adsorbed by palygorskite (Fritsch et al., 2004).

The cause of color in blue opal from Peru was deduced by observation of the color zoning in previous work to be inclusions of chrysocolla $\left[(\mathrm{Cu}, \mathrm{Al})_{2} \mathrm{H}_{2} \mathrm{Si}_{2} \mathrm{O}_{5}(\mathrm{OH})_{4} \cdot \mathrm{nH}_{2} \mathrm{O}\right]$. The presence of $\mathrm{Cu}$ was established by microanalyses with a scanning electron microscope (SEM; Fritsch et al., 1999). The high $\mathrm{Cu}$ concentration of this opal $(7,140 \mathrm{ppm}$ in our measurement) was confirmed, whereas other opals contain almost no $\mathrm{Cu}$. Furthermore, we observed a particularly high $\mathrm{Mg}$ concentration (about 7,200 ppm more than in a typical opal), but no $\mathrm{Al}$ in excess. There are some $\mathrm{Cu}$ silicates which are known to color silica (e.g., Koivula and Kammerling, 1991; Koivula et al., 1993; Vasconcelos et al., 2002; Koivula and Tannous, 2003), but their precise identification is difficult. Here, we can assume that the color is effectively due to inclusions. Their nature remains uncertain, but can be constrained to a few possibilities such as pure chrysocolla (without $\mathrm{Al}$ ), or plancheite $\left[\mathrm{Cu}_{8}\left[(\mathrm{OH})_{4} \mathrm{Si}_{8} \mathrm{O}_{22}\right] \mathrm{H}_{2} \mathrm{O}\right]$. Perhaps a more convincing hypothesis is that $\mathrm{Mg}$, as it appears correlated to $\mathrm{Cu}$, might be present in the form of "bisbeeite", a Mg-rich variety of shattuckite $\mathrm{Cu}_{5}\left(\mathrm{SiO}_{3}\right)_{4}(\mathrm{OH})_{2}$. Note that only opals from Peru and France (Biot, Alpes-Maritimes, but not commercially worked) have such a blue color associated with $\mathrm{Cu}$ silicate inclusions. Blue opals from other localities in the world (example: opal from Owyhee, Oregon) owe their body color to a 
light scattering phenomenon (Rayleigh scattering).

The orange body color of fire opal has been attributed to nano-inclusions of iron-containing products (Fritsch et al., 1999, 2002). In this study, we observed that the intensity of the orange color (from yellow to orange to red to "chocolate"-brown) correlates with the Fe concentration. No other element correlates with Fe. This is consistent with the proposal that these colors are due to ironcontaining nanoscale inclusions, probably Fe-oxyhydroxides.

\subsection{Luminescence and chemical composition}

Opals which emit a luminescence are known to contain uranium (green luminescence) or oxygen-related defects (blue luminescence). An excess of $\mathrm{Fe}^{3+}$ may quench the luminescence (Fritsch et al., 1999). We here use our results to quantify these luminescence phenomena.

Uranium is found in variable amounts in opals showing a green luminescence (up to $130 \mathrm{ppm}$ ). All opals with at least 1 ppm of $U$ display such a luminescence (Fig. 2); a $U$ concentration as low as $0.02 \mathrm{ppm}$ is sometimes sufficient for a green emission. Blue luminescence does not correlate with particular trace element, which is consistent with an origin linked to oxygen-related defects (Fig. 2). One can note that blue luminescence occurs only when the $U$ content is below $1 \mathrm{ppm}$. No luminescence, either blue or green, occurs when the Fe content exceeds 3,000 ppm. This confirms that $\mathrm{Fe}$, probably as $\mathrm{Fe}^{3+}$, quenches any emission.

We also observed that green luminescence is not restricted to common opals, and that the blue variety is not limited to precious opals. The greenish yellow emission affects precious opals as well, including some Australian opals. The blue luminescence concerns mostly Australian opals (both common and precious opals) but also gems from other localities (Mexico, Honduras and Slovakia), 
especially when they are white. This indicates that the distinction between the luminescence of precious and common opals has no chemical ground. Both common and precious opal luminesce green when $\mathrm{U} \geq 1 \mathrm{ppm}$ and $\mathrm{Fe}<1,000$ ppm, and blue when $\mathrm{U}<1 \mathrm{ppm}$ and $\mathrm{Fe}<1,000 \mathrm{ppm}$.

\subsection{Geochemistry of opal host rocks}

Chemical analyses are presented in Table 2 for rocks and in Table 4 for opals. Mexican samples were chosen to represent the volcanic environment, and a Brazilian one to represent the sedimentary environment. The host rocks from Mexico are rhyolites or rhyolitic tuffs. These rocks have experienced various degrees of weathering (see loss on ignition: LOI). In fact, opal was never found next to any unaltered host rock. That is why rock no 774 (La Lupita mine, Jalisco) was sampled: it is an obsidian found in the layer above the opal-bearing rhyolite, and it represents the unaltered rock, whose composition must be similar to the primary unaltered rhyolite. The host rock from Brazil is a sandstone. Multi-elements and REE patterns presented in this work are normalized to chondrite $(\mathrm{C} 1)$ in order to compare directly the compositions of volcanic and sedimentary opals.

The host rock multi-element diagrams are presented in Figs. 3 and 4. All host rocks from Mexico show typical patterns for rhyolite (Fig. 3). Compared to chondrite, they are all enriched and have $\mathrm{Eu}, \mathrm{Sr}$ and also $\mathrm{Ba}$ negative anomalies, which represent the results of plagioclase feldspar fractionation. The multi-element diagram of the Brazilian sandstone (Fig. 4) is compared to the post-Archaean Australian shale (PAAS, Taylor and McLennan, 1985), in order to compare the sandstone pattern with that of typical sedimentary rocks. The two patterns are indeed similar, except for $\mathrm{Rb}$ and $\mathrm{Sr}$ concentrations, which are lower in the Brazilian sandstone.

The comparison between opals and their host rocks are presented in Figs. 5 and 6, as multielements diagrams, normalized to chondrite (C1; Sun and McDonough, 1989). For Mexico, results 
for a representative host rock and its corresponding opal are shown in Fig. 5. Other host rock / opal pairs have the same behavior, the only difference being the variation in concentrations between opal and its host rock. Host rock and opal patterns are very similar in shape. Opals always have a lower concentration in all elements compared to the host rock, which can be attributed to a dilution. The two patterns are near parallel, with however a progressive depletion from Gd to Lu compared to the host rock. The light rare earth element (LREE) - heavy rare earth element (HREE) ratio is still higher in opal than in its host rock. In the example in Fig. 5 (sample no 765), La/Yb $=23$ for opal and $=2.3$ for the rhyolite, meaning that HREE are more fractionated in the opal. This is consistent with the hypothesis of opal coming from host rock dilution; HREE are known to be more incompatible than LREE, and so stay preferentially in the host rock.

The Brazilian sandstone and the associated opal patterns (pair no 766) are presented in Fig. 6. The parallelism between rock and opal is still apparent, though some elements are preferentially concentrated in the opal compared to host rock, such as $\mathrm{Rb}, \mathrm{Ba}, \mathrm{K}$, or $\mathrm{Sr}$; these are elements present in alkali feldspar (e.g., Icenhower and London, 1996). This is because this sandstone is very weathered, as previously noticed from the comparison to PAAS (Fig. 4). There are no remaining feldspar crystals in the sandstone, all were completely altered to other phases during weathering, and their trace elements appear to have been concentrated within the opal. Furthermore, HREE are also less concentrated in the opal than in the sandstone: $\mathrm{La} / \mathrm{Yb}=19$ in opal and 8 in the sandstone.

Both Mexican and Brazilian opals, either volcanic or sedimentary, come from the dilution of the host rock. However, we cannot deduce a dilution factor. Indeed, we would expect that the most altered rocks (with high LOI) will give the highest trace element concentration in "concentrated" opals. This is not true, and can be explained by a further alteration of the host rock, after opal formation. 


\subsection{Opal-A versus $-C T$}

Opal-A and -CT are the two mineralogical types of opal, recognizable by their X-ray diffractograms or Raman spectra. From our sampling covering a broad range of deposits around the world, we have observed that gem opal-CT is always found in a volcanic environment. On the contrary, opal-A forms either in sedimentary (which is the most widespread) or in volcanic environments (examples: Honduras, Slovakia and Mexico).

From our data, the distinction between opal-A and -CT is not related to a specific chemical element; at first sight, the impurity and trace element concentration cover the same range of values. However, a single deposit (such as the one in Honduras) may produce both opal-A and -CT. In this case, concentration of all impurities and traces elements are much lower in opal-A compared to opal-CT sometimes by a factor greater than 100 . We therefore hypothesize that opal-A may form preferentially when elements are less concentrated, at least in a volcanic environment.

\subsection{Play-of-color versus common opal}

McOrist and Smallwood (1997) noted that some precious opals contain fewer impurities than common opals. Our work does not confirm this result. In fact, in both varieties of opals, impurities and trace elements have an average total concentration of about $0.96 \mathrm{wt} . \%$. However, precious opals tend to have a more constant impurity concentration than common opals, which can have either very high or very low concentrations. The concentration of impurities and trace elements in precious opals varies by a factor of 10 between the minima and the maxima value, whereas in common opals it varies by a factor of more than 430; this also applies to REE. A comparison of Brazilian precious and common opal's REE patterns is given in Fig. 7. It appears that precious opals are restricted to a smaller range of element concentration than common opals. This is true for all 
deposits that we sampled.

\subsection{Volcanic versus sedimentary opal}

From our analyses, $\mathrm{Ba}$ seems to be characteristic of the geological environment of opal formation (Fig. 8). Sedimentary opals always contain $>110 \mathrm{ppm} \mathrm{Ba,} \mathrm{whereas} \mathrm{volcanic} \mathrm{opals} \mathrm{always}$ have less. From the literature, biogenic sedimentary opal-A contains at least 120 ppm Ba (e.g., Dehairs et al., 1980). It seems that this concentration is the minimum for sedimentary opal in general. Sedimentary opals are formed in sandstones, which themselves are derived from the weathering and erosion of continental rocks. Barium, most often contained in detrital feldspars, has been liberated through multiple weathering cycles, and is easily dissolved in water from which opals form (e.g., Fagel et al., 1999; Davidson et al., 2005). In a volcanic environment, feldspars have undergone only one cycle of weathering, hence the Ba content in water is much lower.

Furthermore, REE diagrams of opals from volcanic and sedimentary environments show significant differences. Figure 9 presents typical examples of sedimentary opals from Australia compared to volcanic ones from Mexico. They both generally show depletion from HREE to LREE, and have concentrations from about 500 times depleted to 400 times enriched in LREE. The REE patterns of volcanic opals show the typical negative Eu anomaly inherited from the host rock (Fig. 9a). A Ce anomaly is almost always present in opal REE patterns; it can be positive or negative. This anomaly is not present in the host rock (Fig. 3), which means that it develops during weathering. The transformation of $\mathrm{Ce}^{3+}$ into $\mathrm{Ce}^{4+}$ occurs under oxidizing conditions, giving a positive anomaly (and vice versa). REE patterns of sedimentary opals have little to no Eu anomaly (Fig. 9b), and no Ce anomaly. Typically, sedimentary rocks have a small Eu anomaly (Fig 4, with Brazilian sandstone and PAAS), which is also visible in the opal pattern, but generally reduced. 


\subsection{Variations with geographic origin}

Calcium is the only element that varies significantly with the geographic origin of the samples (Fig. 10). Opal-A from Honduras have the lowest concentrations in $\mathrm{Ca}$, whereas opals from Ethiopia have the highest. Calcium concentration can therefore often be useful in combination with other criteria to determine the geographical origin of an opal.

Opals coming from very different deposits can look very much alike in color, play-of-color or crystallinity (opal-A and -CT). For example, fire opals (and yellow to brown opals in general) are found in Mexico (the most famous source of this kind of opal), Ethiopia, Kazakhstan and the USA (Opal Butte, Oregon). This makes the determination of opal's geographical origin uneasy. Nonetheless, some colors are found in few localities only: for example, pink opals are found only in Mexico, Peru and France.

The geochemical criteria explored in this work may help in determining the geographical origin, in particular of fire opals and white opals. Ba concentration and the shape of REE pattern are strong indications of the geologic environment of opals, and $\mathrm{Ca}$ concentration is useful to separate some deposits (Figs. 10 and 11). The most useful criteria are listed below for each color category of opal.

Orange to brown opals: This series is widespread in volcanic deposits, and we studied such opals from Mexico, Ethiopia, Kazakhstan, Slovakia and the USA. Opals colored with supposed Fecontaining nano-inclusions can have a yellow to orange to red to brown color. Opals from Ethiopia are easily distinguishable from other opals because of their high value in $\mathrm{Ca}$ (>1,000 ppm; Fig.10), combined with the presence of $\mathrm{Nb}(>2 \mathrm{ppm})$. However, it was said in previous work (Johnson et al., 1996; Kinnaird, 2002) that $\mathrm{Nb}$ was an element only present in opal from Ethiopia. Even if indeed all Ethiopian opals contain $\mathrm{Nb}$, opals from other localities can have significant concentration in $\mathrm{Nb}$, 
such as those from Tintenbar, Australia (around 3 ppm), and Mexico (opal no 769: 32 ppm). Ethiopian opals show generally (7 out of 8) a REE pattern with a positive Ce anomaly, whereas elsewhere in volcanic environments, opals have a negative Ce anomaly (Fig. 11a). This may indicate that during the formation of Ethiopian opals, conditions were oxidizing. Slovakian gem orange opals are distinct from those of other localities because they are opal-A. Other deposits of fire opals are in a volcanic setting, and so form mainly opal-CT. Their REE patterns are however typical of a volcanic environment (Fig. 11b). Opals from Opal Butte, Oregon, USA (in general, not only fire opals) have a unique REE pattern (Fig. 11c), with a flat "V" shape. Instead of being depleted in HREE like other opals, they are enriched in HREE compared to LREE, with highest concentration for middle REE (MREE). Mexican and Kazakhstan opals overlap in the $\mathrm{Ca} / \mathrm{Ba}$ diagram (Fig. 10); their REE patterns are both typical of volcanic deposits (cf. Figs. 3b-11d). However, Kazakhstan opals have a lesser Eu anomaly than Mexican samples. They can be otherwise separated on the basis of their $\mathrm{Mg}$ and $\mathrm{Sr}$ concentration, being higher for Kazakhstan than Mexico (more than $250 \mathrm{ppm}$ and $15 \mathrm{ppm}$ respectively). Mexican deposits cannot be differentiated among themselves by their trace elements. Indeed, the opal host rock is of a remarkably constant nature throughout the country, at least enough to give rise to opals with essentially the same chemical profile. The only exception is the Los Laureles mine (Jalisco), as mentioned above, with a characteristic REE pattern in a flat inverse "U" shape (Fig. 11e), whereas the general shape of Mexican opals is depleted from LREE to HREE (Fig.3b).

White opals: White (or milky) opals come especially from Australia, with a lesser percentage from Brazil and Honduras. They can be common or precious opals, the last variety being naturally more in demand. Firstly, white opals formed in volcanic and sedimentary environments can be separated on the basis of their Ba content, so there remains to separate Australian from Brazilian opal-A, and Honduran from Brazilian opal-CT. Honduran and Brazilian opals are not overlapping in the $\mathrm{Ba} / \mathrm{Ca}$ diagram (Fig. 10), so these opal-CT are easily separated. Another criterion to distinguish Honduran 
from Brazilian opal-CT is their $\mathrm{Al}$ and $\mathrm{K}$ content, which is more important for Honduran opals $(>2,400 \mathrm{ppm}$ and $>600 \mathrm{ppm}$, respectively) than for Brazilian opals $(<1,700 \mathrm{ppm}$ and $<400 \mathrm{ppm}$, respectively). Australian and Brazilian opal-A can be differentiated through their $\mathrm{Al}$ and $\mathrm{Mg}$ concentration. Australian opals have $\mathrm{Al} / \mathrm{Mg}$ ratio $>20$, while it is $<10$ for Brazilian opals. Australian opals formed in the Great Artesian Basin cannot be separated from each other on the basis of their chemical composition. As for Mexican opals, the geological formation in which these opals form is the same and provides no significant differences in chemical signature. On the contrary, Australian opal-CT are easy to recognize, because of the differences in the geological setting. Opals from Norseman contain only a few impurities, mainly restricted to $\mathrm{Al}, \mathrm{Na}, \mathrm{Mg}$, and Fe, and no REE. In contrast, opals from Tintenbar are very similar to Mexican opals. It is therefore possible to distinguish opal provinces, but not individual mines in general.

Pink opals: These come from Peru and Mexico. As stated above, they can be separated on the basis of their concentration in palygorskite (see section 4.2). The French pink opal ("Quincyite") is unambiguously identified by its sepiolite (another variety of phyllosilicate) inclusions.

For other varieties (blue opals for example), we did not have enough samples to derive meaningful distinguishing criteria.

\subsection{Further work}

In view of the present results, some further directions of research appear manifest. As in all preliminary studies, results need to be confirmed by further analyses, in particular the comparison of opal to their host rocks. However, the consistency of the present results suggests that our conclusions may have some merit. In addition, this geochemical approach does not offer clues about the very restrictive chemistry of the opal-forming fluids. We know only that they carry silica and 
some other impurities and traces, while traversing rocks with wt.\% concentrations of many of these elements. This is actually a broader question, relevant not only to opal, but also to other silica minerals, in particular chalcedony. This same relatively pure silica solution is observed during the formation of amethyst in geodes from the Rio Grade do Sul basalt flows in Brazil, sometimes with an opal/chalcedony/quartz sequence (Epstein, 1988 and references therein). Also chalcedony forms during the weathering of serpentine (e.g., Willing and Stocklmayer, 2003). From opal synthesis in the laboratory, it appears that $\mathrm{pH}$ at the time of deposition is an important factor (Darragh and Gascin, 1966; Darragh et al., 1966). However this parameter cannot be determined directly. Further studies will need to explore this and possibly further parameters in order to provide answers to this nagging question.

\section{Conclusions}

The trace element chemistry of gem opals seems to be linked to that of the host rock - at least for samples in this study. Indeed, opals and their host rocks have nearly identical REE patterns. The only differences are a "dilution factor" in opal compared to its host rock, and a depletion from LREE to HREE (explained by the higher mobility of LREE compared to HREE). This result would confirm that opals, either opal-A or -CT, are deposited by circulating fluids.

Furthermore, we found no systematic chemical differences between opal-A and -CT. This means that the crystallinity is independent of the chemical composition of the host rocks. This is consistent with Rondeau et al. (2004), who proposed that it is in fact dependent on the temperature of formation, which is "low" for opal-A (about $45^{\circ} \mathrm{C}$ ) and "high" for opal-CT (about $170^{\circ} \mathrm{C}$ ). Other, non-chemical parameters may possibly come into play. 
The formation of precious versus common opal seems however to depend on the chemistry. Precious opals do not have less impurities in general as McOrist et al. (1997) stated, but they are formed in a more restricted, more "homogenized", set of chemical composition than common opals: the content in trace and impurities describes a narrower range of values. However, considering that there is an overlap between the two varieties of opals, another factor at least must be implicated in the formation of one or the other variety.

The composition of opals influences some physical properties. Not surprisingly, color is often dependent on chemical impurities: almost all color opals are colored by impurities, while some are colored by mineral inclusions. This is the case of Peruvian blue opals which contain some $\mathrm{Cu}$ silicate, and of fire opals (and most yellow to brown opals) which contain $\mathrm{Fe}^{3+}$ in the form of nanocrystalline compounds. Other examples are known in the literature, such as orange opaque opals from Austria ("forcherite"), which are colored by inclusions of realgar (Bojar and Taucher, 1994, 1995). The luminescence is influenced by elements too. The presence of traces of $U$ induces a green luminescence (always if $>1 \mathrm{ppm}$ ), whereas Fe inhibits any luminescence above a certain concentration (about 3,000 ppm), presumably via the well known $\mathrm{O}^{2-} \rightarrow \mathrm{Fe}^{3+}$ charge transfer. Furthermore, blue luminescence is particularly common in sedimentary environments, or more generally in environments which do not contain U.

The geological and geographic origin of opals can be inferred from trace element analyses. Opals from sedimentary environments are characterized by a high Ba concentration (from 118 to 300 ppm), and a typical REE pattern (which show depletion from LREE to HREE, without any noticeable anomaly). On the opposite, opals from volcanic environments have lower $\mathrm{Ba}$ concentration (below $110 \mathrm{ppm}$ ) and typical REE patterns with negative anomaly in Eu, and positive or negative anomaly in Ce (depending on the oxidation conditions). 
Determining the geographic origin of an opal is often possible. This can be achieved through the determination of the nature of the inclusions (seen in Raman for example) or by combining trace element concentrations with rare earth patterns. Within the same deposit or opal-bearing region (opals from the Great Artesian Basin in Australia and opals from the central high plateaus of Mexico), it is generally not possible to distinguish between the different mines, because of the overall similar chemical signature of the host rock. But above the regional scale, there are enough differences to distinguish the different provenances.

Our analyses on opals were performed by dilution with an ICP-MS, and we were not able to run the laser ablation correctly. The next step is to make laser ablation possible in order to make the procedure almost non-destructive (only small craters of up to $50 \mu \mathrm{m}$ would be left at the surface), and thus apply it to cut stones of high value.

\section{Acknowledgements}

Deocleciano Bittencourt Rosa, Yves Bodeur, François Champreux, Jean-Pierre Gauthier, Susan Hendrickson, Jaroslav Hyrsl, Yves Lulzac, Francesco Mazzero, Sadao and Satochi Mochizuki, Blanca Mocquet, Juergen Schuetz, Cédric Simonet, Mark Tremonti and Alexandre Wolkonsky, provided information and samples. The authors wish also to thank Karine David and Mhammed Benbakkar for conducting major and trace analysis on rocks.

\section{References}

Bartoli, F., Meyer, R., Moura, F., Samama, J.C., 1983. Caractérisation chimico-minéralogique de l'opale noble des gisements nord-est du Brésil. Comptes Rendus de l'Académie des Sciences de Paris 296, 625630.

Bartoli, F., Bittencourt Rosa, D., Doirisse, M., Meyer, R., Philippy, R., Samama, J.C., 1990. Role of aluminium in the structure of Brazilian opals. European Journal of Mineralogy 2, 611-619. 
Bayliss, P., Males, P.A., 1965. The mineralogical similarity of precious and common opal from Australia. Mineralogical Magazine 35, 429-431.

Bojar, H.-P., Taucher, J., 1994. 659: Arsenolith, Realgar und Auripigment im "Forcherit" vom Ingeringgraben bei Knittelfeld, Steiermark. In: Niedermayr, V.G., Bojar, H.P., Brandstätter, F., Hammer, V.M.F., Moser, B., Postl, W., Taucher, J. (Eds.), Neue Mineralfunde aus Österreich XIIIL. Carinthia II 184/104, p. 265-266.

Bojar, H.-P., Taucher, J., 1995. 996: Pharmakosiderit von der "Forcheritfundstelle" im Ingeringgraben bei Knittelfeld, Steiermark. In: Niedermayr, V.G., Bojar, H.P., Brandstätter, F., Hammer, V.M.F., Moser, B., Postl, W., Taucher, J. (Eds.), Neue Mineralfunde aus Österreich XIVL. Carinthia II 185/105, p. 163.

Bouhnik-Le Coz, M., Petitjean, P., Serrat, E., Gruau, G., 2001. Validation d'un Protocole Permettant le Dosage Simultané des Cations Majeurs et Traces dans les Eaux Douces Naturelles par ICP-MS. Collection Les Cahiers Techniques de Géosciences Rennes, 1, 99 pp. [http://geosciences2.univrennes1.fr/IMG/pdf/Cahier_n1.pdf].

Cantagrel, F., Pin, C., 1994. Major, minor and rare-earth element determinations in 25 rock standards by ICP atomic emission spectrometry. Geostandards Newsletter 18, 123-38.

Darragh, P.J., Gaskin, A. J., 1966. The Nature and origin of opal. Australian Gemmologist 66, 80-90.

Darragh, P.J., Gaskin, A.J., Terrell, B.C., Sanders, J.V., 1966. Origin of precious opal. Nature 209, 13-16.

Davidson, P., Kamenetsky, V., Cooke, D., Frikken P., 2005. Magmatic Precursors of Hydrothermal Fluids at the Río Blanco Cu-Mo Deposit, Chile: Links to Silicate Magmas and Metal Transport. Economic Geology 100, 963-978.

Dehairs, F., Chesselet, R., Jedwab, J., 1980. Discrete suspended particles of barite and the barium cycle in the open ocean. Earth and Planetary Science Letters 49, 528-550.

Des Cloizeaux, A., 1862. Manuel de Minéralogie. Dunod (Ed.) Paris, 572 pp.

Elzea, J.M., Rice, S.B., 1996. TEM and X-ray diffraction evidence for cristobalite and tridymite stacking sequences in opal. Clays and Clay Minerals 44, 492-500.

Epstein, D.S., 1988. Amethyst mining in Brazil. Gems and Gemology 24, 214-228.

Fagel, N., André, L., Dehairs, F., 1999. Advective excess Ba transport as shown from sediment and trap geochemical signatures. Geochimica et Cosmochimica Acta 63, 2353-2367.

Fritsch, E., Rondeau, B., Ostrooumov, M., Lasnier, B., Marie, A.-M., Barrault, A., Wery, J., Connoué, J., 
Lefrant, S., 1999. Découvertes récentes sur l'opale, Revue de gemmologie a.f.g. 138/139, 34-40.

Fritsch, E., Mihut, L., Baibarac, M., Baltog, I., Ostrooumov, M., Lefrant, S., Wéry, J., 2001. Luminescence of oxidized porous silicon: surface-induced emissions from disordered silica micro- to nanotextures. Journal of Applied Physics 90, 4777- 4782.

Fritsch, E., Ostrooumov, M., Rondeau, B., Barreau, A., Albertini, D., Marie, A.-M., Lasnier, B., Wery, J., 2002. Mexican gem opal: nano- and micro-structure, origin of color and comparison with other common opals of gemmological significance. The Australian Gemmologist 21, 230- 233.

Fritsch, E., Wéry, J., Jonusauskas, G., Faulques, E., 2003. Transient photoluminescence from highly disordered silica-rich natural phases with and without nanostructures. Physics and Chemistry of Minerals $30,393-400$.

Fritsch, E., Gaillou, E, Ostroumov, M., Rondeau, B., Devouard, B., Barreau, A., 2004. Relationship between nanostructure and optical absorption in fibrous pink opals from Mexico and Peru. European Journal of Mineralogy 16, 743-752.

Giuliani, G., Chaussidon, M., Schubnel, H.-J., Piat, D., Rollion-Bard, C., France-Lanord, C., Giard, D., De Narvaez, D., Rondeau, B., 2000. Oxygen isotopes and emerald trade routes since antiquity. Science 287, 631-633.

Gübelin, E., 1986. Les opales mexicaines. Revue de gemmologie a.f.g. 88, 3-6.

Holzhey, G., 1997. Feueropal von Opal Butte, Oregon, USA. Zeitschrift der Deutsche Gemmologische Gesellschaft 46, 161-167.

Horton, D., 2002. Australian sedimentary opal: why is Australia unique? The Australian Gemmologist 21, 8.

Icenhower, J., London, D., 1996. Experimental partitioning of Rb, Cs, Sr, and Ba between alkali feldspar and peraluminous melt. American Mineralogist 81, 719-734.

Johnson, M.L., Kammerling, R.C., DeGhionno, D.G., Koivula, J.I., 1996. Opal from Shewa province, Ethiopia. Gems and Gemology 32, 112-120.

Jones, J.B., Segnit, E.R., 1971. The nature of opal. Part 1: Nomenclature and constituent phases. Journal of the Geological Society of Australia 8, 57-68.

Kinnaird, J.A., 2002. A note on chocolate-brown opal associated with volcanic rocks in Somaliland. Journal of Gemmology 28, 81-84.

Kinnaird, J.A., Jackson, B., 2000. Somaliland - a potential gem producer in the Mozambique belt. Journal of 
Gemmology 27, 139-154.

Koivula, J.I., Fryer, C.W., Keller, C.P., 1983. Opal from Queretaro, occurrence and inclusions. Gems and Gemology 19, 87-98.

Koivula, J.I., Kammerling, R .C., 1991. Gem News: Drusy gems in jewelry. Gems and Gemology 27, 49.

Koivula, J.I., Kammerling, R.C., Fritsch, E., 1993. Gem News: Chalcedony colored by mineral inclusions. Gems and Gemology 29, 208-209.

Koivula, J.I., Tannous, M., 2003. Lab Note: Chrysocolla « owl» agate. Gems and Gemology 39, 314.

Lacroix, A., 1896. Minéralogie de la France. 1962 reprint, A. Blanchard Ed., Paris. volume II, p. 446 and volume III, p. 316-337.

Louis, M., Guillemin, C.J., Goni, J.C., Ragot, J.P., 1968. Coloration rose-carmin d'une sépiolite Eocène, la quincyte, par des pigments organiques. Advances in Organic Geochemistry, 553-566.

McOrist, G.D., Smallwood, A., 1995. Trace elements in colored opals using neutron activation analysis. Journal of Radioanalytical and Nuclear Chemistry 198, 499-510.

McOrist, G.D., Smallwood, A., 1997. Trace elements in precious and common opals using neutron activation analysis. Journal of Radioanalytical and Nuclear Chemistry 223, 9-15.

McOrist, G.D., Smallwood, A., Fardy, J.J., 1994. Trace elements in Australian opals using neutron activation analysis. Journal of Radioanalytical and Nuclear Chemistry 185, 293-303.

Neymark, L.A., Amelin, Y.V., Paces, J.B., 2000. ${ }^{206} \mathrm{~Pb}-{ }^{230} \mathrm{Th}_{-}-{ }^{234} \mathrm{U}-{ }^{238} \mathrm{~Pb}$ and ${ }^{207} \mathrm{~Pb}-{ }^{235} \mathrm{U}$ geochronology of Quaternary opal, Yucca Mountain, Nevada. Geochimica et Cosmochimica Acta 64, 2913-2928.

Payette, F., 1999. A propos de l'opale australienne. Revue de gemmologie a.f.g. 138-139, 67-71.

Pewkliang, B., Pring, A., Brugger, J., 2004. Opalisation of fossil bone and wood: clues to the formation of precious opal. Regolith 2004, 264-268.

Ostrooumov, M., Fritsch, E., Lasnier, B., Lefrant, S., 1999. Spectres Raman des opales: aspect diagnostique et aide à la classification, European Journal of Mineralogy 11, 899-908.

Rondeau, B., Fritsch, E., Guiraud, M., Renac, C., 2004. Opals from Slovakia («Hungarian » opals): a reassessment of the conditions of formation. European Journal of Mineralogy 16, 789-799.

Sanders, J.V., 1964. Color of precious opal. Nature 204, 1151-1153.

Smallwood, A.G., 1999. Chemical and physical evaluation of Australian Precious Opal. Unpublished M.Sc. thesis, University of Technology, Sydney, Australia. 
Smallwood, A.G., Thomas, P.S., Ray, A.S., 1997. Characterisation of sedimentary opals by Fourier Transform Raman spectroscopy. Spectrochimica Acta A 53, 2341-2345.

Sun, S.-S., McDonough, W.F., 1989. Chemical and isotopic systematics of ocean basalts: implications for mantle composition and processes. In: Saunders, A.D., Norry, M.J. (Eds.), Magmatism in the Ocean Basins, Geological Society Special Publication 42, 313-345.

Taylor, S.R., McLennan, S.M., 1985. The Continental Crust: Its Composition and Evolution. Oxford: Blackwell Scientific Publication, 312 pp.

Vasconcelos, P., Cohen, B., Calos, N., 2002. Color in quartz: from atomic substitutions to nanoinclusions. Australian Gemmologist 21, 278.

Webb, J.A., Finlayson, B.L., 1987. Incorporation of $\mathrm{Al}, \mathrm{Mg}$, and water in opal-A: evidence from Speleothems. American Mineralogist 72, 1204-1210.

Willing, M.J., Stocklmayer, S.M., 2003. A new chrome chalcedony occurrence from Western Australia. Journal of Gemmology 28, 265-279.

Yeghicheyan, D., Carignan, J., Valladon, M., Bouhnik-Le Coz, M., Le Cornec, F., Castrec, M., Robert, M., Aquilina, L., Aubry, E., Churlaud, C., Dia, A., Deberdt, S., Dupré, B., Gruau, G., Hénin, O., De Kersabiec, A.-M., Petitjean, P., Serrat, E., 2002. A Compilation of some trace elements measured in the natural river water standard SLRS4. Geostandards Newsletter 25 (2-3), 465-475.

Zielinski, R.A., 1982. Uraniferous opal, Virgin Valley, Nevada: conditions of formation and implications for uranium exploration. Journal of Geochemical Exploration 16, 197-216.

\section{Figure captions}

Fig. 1. Correlation between the sum of the most common trivalent ions $(\mathrm{Al}+\mathrm{Fe})$ and monovalent and divalent ions $(\mathrm{Na}+\mathrm{Mg}+\mathrm{Ca}+\mathrm{Ba}+\mathrm{K})$. It is explained by a "pseudo-crystallochemistry" of opals. The charge imbalance produced by the substitution of $\mathrm{Al}$ and $\mathrm{Fe}$ for $\mathrm{Si}$ is compensated by some monovalent and divalent ions. A small number of opals do not follow this rule perfectly, but are nevertheless close to the general trend.

Fig. 2. Green versus blue luminescence, as a function of $U$ and Fe content. Green and blue squares represent respectively intense green and blue luminescence, whereas empty squares represent weak luminescence. 
Black squares represent inert opals. The more Fe an opal contains, the less it luminescences. The green luminescence is correlated with $\mathrm{U}$ content. Blue luminescence occurs when $\mathrm{U}<1 \mathrm{ppm}$ and $\mathrm{Fe}$ $<1,000 \mathrm{ppm}$.

Fig. 3. Multi-element diagram of Mexican opal's host rocks normalized to chondrite. They have a typical pattern for rhyolites, with $\mathrm{Ba}, \mathrm{Sr}$ and Eu negative anomalies.

Fig. 4. Multi-element diagram of Brazilian opal's host rock and PAAS (Taylor and McLennan, 1983) normalized to chondrite. Brazilian sandstone and PAAS are near parallel, which means that the sandstone is a typical sedimentary rock.

Fig 5. Multi-element diagram of a Mexican opal compared to its rhyolitic host rock normalized to chondrite (couple no 765). The two patterns are near parallel, with always a lesser element concentration in opal compared to its host rock. The depletion in HREE compared to LREE ( $\mathrm{La} / \mathrm{Yb}$ greater in opal than in rhyolite) is explained by a lesser mobility of HREE, which stay preferentially in the rock during weathering.

Fig. 6. Multi-element diagram of a Brazilian opal compared to its sandstone host rock normalized to chondrite (couple no 766). The two patterns are near parallel, except for $\mathrm{Rb}, \mathrm{Ba}, \mathrm{K}, \mathrm{Sr}$, which are more concentrated in opal. Depletion in HREE compared to LREE is explained by a lesser mobility of HREE, which stay preferentially in the rock during weathering.

Fig. 7. REE distribution patterns for play-of-color and common opals from Brazil. Play-of-color opals are restricted to a narrower range of REE content variations than common opals.

Fig. 8. The Ba content of opal can help separate volcanic $(<110 \mathrm{ppm})$ from sedimentary $(>110 \mathrm{ppm})$ gem opals.

Fig. 9. Chondrite-normalized REE distribution patterns of opals of volcanic and sedimentary origin, represented by examples from Mexico and Australia respectively. They both show a depletion from HREE to LREE. (a) The range of patterns for Mexican opals, which always have a negative Eu anomaly and often a negative Ce anomaly. (b) The range of patterns for Australian opals, which have little to no $\mathrm{Eu}$ and $\mathrm{Ce}$ anomalies.

Fig. 10. Ba versus Ca diagram to identify an opal's geographic origin. Ellipsoids represent a visual guide for the dispersion of points for each opal-producing region.

Fig. 11. Chondrite-normalized REE distribution patterns of opals from different geographic origins. (a) 
Ethiopia: typical depletion from LREE to HREE, Eu negative anomaly and generally a positive Ce anomaly (one sample not), helpful to distinguish them from other opals. (b) Slovakia: almost flat shape, only a small negative Eu anomaly. (c) USA: flat "V" shape with a high negative Eu anomaly, characteristic of opals from this origin. (d) Kazakhstan: typical depletion from LREE to HREE; small negative anomaly in Eu, less intense than that in Ce. (e) Los Laureles mine, Jalisco, Mexico: this deposit is the only one which can be differentiated from other Mexican deposits, with its REE patterns in flat inverse " $U$ "; the intense negative anomaly in Eu is present, as in other Mexican deposits. 
Table 1. Characteristics of opal samples in this study (Abbreviations: Qr, Queretaro; Jal, Jalisco; Nay, Nayarit; C, common opal; P, precious opal; Luminescence: G-Y, greenish yellow; B, blue).

\begin{tabular}{|c|c|c|c|c|c|}
\hline Sample & Country, state, mine & Colour & $\mathrm{C} / \mathrm{P}$ & Raman & Luminesce \\
\hline \multicolumn{6}{|l|}{ Peru } \\
\hline 620 & Acari & Blue & $\mathrm{C}$ & $\mathrm{CT}$ & G-Y \\
\hline QOP3 & Acari & Pink & $\mathrm{C}$ & CT & G-Y \\
\hline \multicolumn{6}{|l|}{ Mexico } \\
\hline 643 & Durango, Mapimi & Pink & $\mathrm{C}$ & CT & G-Y \\
\hline 267 & Durango, Mapimi & White & $\mathrm{C}$ & $\mathrm{CT}$ & G-Y \\
\hline 267 & Durango, Mapimi & White & $\mathrm{C}$ & $\mathrm{CT}$ & G-Y \\
\hline 799 & Qr, Olimpia & "Fire" & $\mathrm{P}$ & $\mathrm{CT}$ & No \\
\hline 730 & Qr, Olimpia & Yellow & $\mathrm{C}$ & CT & G-Y \\
\hline 801 & Qr, Guacamaya & "Fire" & $\mathrm{C}$ & $\mathrm{CT}$ & No \\
\hline $767 \mathrm{~B}$ & Qr, Guacamaya & Red & $\mathrm{C}$ & $\mathrm{CT}$ & No \\
\hline $768 \mathrm{~A}$ & Qr, Iris & Milky white & $\mathrm{C}$ & $\mathrm{CT}$ & No \\
\hline $768 \mathrm{~B}$ & Qr, Iris & "Fire" & $\mathrm{C}$ & $\mathrm{CT}$ & No \\
\hline 770 & Qr, Carbonera & Red & $\mathrm{C}$ & $\mathrm{CT}$ & No \\
\hline 771 & Qr, Cerro Viejo & Yellow & $\mathrm{C}$ & $\mathrm{CT}$ & No \\
\hline 626 & Qr, Cerro Viejo & Milky white & $\mathrm{C}$ & $\mathrm{CT}$ & No \\
\hline 627 & Qr, Cerro Viejo & Fire & $\mathrm{C}$ & $\mathrm{CT}$ & No \\
\hline 628 & Qr, Cerro Viejo & Red & $\mathrm{C}$ & CT & No \\
\hline 798 & $\mathrm{Qr}, \mathrm{La} \mathrm{Fe}$ & "Fire" & $\mathrm{C}$ & $\mathrm{CT}$ & No \\
\hline 747 & $\mathrm{Qr}, \mathrm{La} \mathrm{Fe}$ & Milky white & $\mathrm{C}$ & CT & G-Y \\
\hline Jal2S & Jal, Los Laureles & Red & $\mathrm{C}$ & $\mathrm{CT}$ & No \\
\hline Jal2D & Jal, Los Laureles & Opaque orange & $\mathrm{C}$ & CT & G-Y \\
\hline 800 & Jal, Los Laureles & "Fire" & $\mathrm{P}$ & $\mathrm{CT}$ & No \\
\hline $629 \mathrm{~A}$ & Jal, Los Laureles & Yellow & $\mathrm{C}$ & CT & No \\
\hline $629 B$ & Jal, Los Laureles & Uncoloured & $\mathrm{C}$ & $\mathrm{CT}$ & No \\
\hline 630 & Jal, Los Laureles & Red & $\mathrm{C}$ & CT & No \\
\hline 772 & Jal, Lupita & Light yellow & $\mathrm{C}$ & CT & G-Y \\
\hline 774 & Jal, Lupita & Red & $\mathrm{P}$ & CT & No \\
\hline 773 & Jal, San Martin & Yellow & $\mathrm{C}$ & CT & No \\
\hline 769 & Jal, San Martin & Brown & $\mathrm{C}$ & $\mathrm{CT}$ & No \\
\hline 631 & Jal, San Martin & Red & $\mathrm{C}$ & CT & No \\
\hline 765 & Nay, Guadalupa & Cream & $\mathrm{C}$ & CT & G-Y \\
\hline $623 \mathrm{~A}$ & Nay, Guadalupa & Chocolate & $\mathrm{C}$ & $\mathrm{CT}$ & No \\
\hline $623 \mathrm{~B}$ & Nay, Guadalupa & Brown & $\mathrm{C}$ & $\mathrm{CT}$ & No \\
\hline 624 & Nay, Guadalupa & Fire & $\mathrm{C}$ & CT & No \\
\hline 625 & Nay, Guadalupa & White & $\mathrm{P}$ & $\mathrm{CT}$ & B \\
\hline
\end{tabular}

\section{Ethiopia}

$\begin{array}{cccc}\text { Chocolate } & \text { C } & \text { CT } & \text { No } \\ \text { Cream } & \text { C } & \text { CT } & \text { G-Y } \\ \text { Uncoloured } & \text { C } & \text { CT } & \text { G-Y } \\ \text { Contraluz } & \text { P } & \text { CT } & \text { G-Y } \\ \text { White } & \text { C } & \text { CT } & \text { G-Y } \\ \text { Chocolate } & \text { P } & \text { CT } & \text { No } \\ \text { Yellow } & \text { P } & \text { CT } & \text { G-Y } \\ \text { Yellow } & \text { C } & \text { CT } & \text { G-Y }\end{array}$

\section{Honduras}




\begin{tabular}{|c|c|c|c|c|c|}
\hline Sample & Country, state, mine & Colour & $\mathrm{C} / \mathrm{P}$ & Raman & Luminescence. \\
\hline $632 \mathrm{~B}$ & & White & $\mathrm{C}$ & $\mathrm{CT}$ & $\mathrm{B}$ \\
\hline 633 & & White & $\mathrm{P}$ & $\mathrm{CT}$ & B \\
\hline 634 & & Light yellow & $\mathrm{C}$ & $\mathrm{CT}$ & No \\
\hline 635 & & Uncoloured & $\mathrm{C}$ & $\mathrm{CT}$ & G-Y \\
\hline 787 & & White & $\mathrm{C}$ & $\mathrm{A}$ & G-Y \\
\hline 791 & & White & $\mathrm{C}$ & A & G-Y \\
\hline \multicolumn{6}{|l|}{ Brazil } \\
\hline 621 & & Yellow green & $\mathrm{C}$ & $\mathrm{CT}$ & G-Y \\
\hline 622 & Rio Grande do Sul & Yellow & $\mathrm{C}$ & $\mathrm{CT}$ & No \\
\hline 761 & Para & Yellow & $\mathrm{C}$ & $\mathrm{CT}$ & No \\
\hline 762 & Para & White & $\mathrm{C}$ & $\mathrm{CT}$ & G-Y \\
\hline 763 & Piaui, PedroII & Milky white & $\mathrm{P}$ & A & G-Y \\
\hline 766 & Piaui, PedroII & Milky white & $\mathrm{P}$ & A & G-Y \\
\hline \multicolumn{6}{|c|}{ Australia } \\
\hline 827 & NSW, Lightning Ridge & Grey & $\mathrm{P}$ & A & G-Y \\
\hline 234 & NSW, Lightning Ridge & Grey & $\mathrm{C}$ & A & B \\
\hline 234 & NSW, Lightning Ridge & Grey & $\mathrm{P}$ & A & B \\
\hline 847 & SA, Mintabie & Grey & $\mathrm{C}$ & A & B \\
\hline 839 & SA, Quilpie & White & $\mathrm{P}$ & A & B \\
\hline 832 & SA, Coober Pedy & White & $\mathrm{P}$ & A & B \\
\hline 835 & SA, Coober Pedy & White & $\mathrm{P}$ & $\mathrm{A}$ & B \\
\hline 844 & SA, Andamooka & Cream & $\mathrm{C}$ & A & B \\
\hline 818 & WA, Norseman & White & $\mathrm{C}$ & $\mathrm{CT}$ & B \\
\hline $387 \mathrm{C}$ & NSW Tintenbar & Brown & $\mathrm{C}$ & $\mathrm{CT}$ & B \\
\hline $387 \mathrm{~N}$ & NSW, Tintenbar & Brown & $\mathrm{P}$ & $\mathrm{CT}$ & B \\
\hline \multicolumn{6}{|c|}{ Slovakia } \\
\hline 204.2 & & Orange & $\mathrm{C}$ & A & No \\
\hline 650 & & Brown & $\mathrm{C}$ & $\mathrm{CT}$ & No \\
\hline \multicolumn{6}{|c|}{ Kazakhstan } \\
\hline 107 & & "Fire" & $\mathrm{C}$ & $\mathrm{CT}$ & No \\
\hline 652 & & "Fire" & $\mathrm{C}$ & $\mathrm{CT}$ & No \\
\hline 653 & & "Fire" & $\mathrm{C}$ & $\mathrm{CT}$ & No \\
\hline \multicolumn{6}{|c|}{ Tanzania } \\
\hline 793 & & Yellow & $\mathrm{C}$ & $\mathrm{CT}$ & No \\
\hline 794 & & Green & $\mathrm{C}$ & $\mathrm{CT}$ & No \\
\hline \multicolumn{6}{|l|}{ USA } \\
\hline 795 & Oregon, Owyhee & Blue & $\mathrm{C}$ & $\mathrm{CT}$ & No \\
\hline 796 & Oregon, Opal butte & White & $\mathrm{C}$ & $\mathrm{CT}$ & No \\
\hline 797 & Oregon, Opal Butte & "Fire" & $\mathrm{C}$ & $\mathrm{CT}$ & No \\
\hline
\end{tabular}


Table 2. Concentration in major and trace elements of opal host rocks from Mexico and Brazil. The corresponding opals have the same sample number as their host rock (Qr, Queretaro; Guaca, Guacamaya; Carbo., Carbonera). Numbers marked with a "*" represent rocks sampled in the same deposit than opal, but not in direct contact with opal.

\begin{tabular}{|c|c|c|c|c|c|c|c|c|c|c|}
\hline \multirow{4}{*}{ \%oxide } & \multicolumn{9}{|c|}{ MEXICO } & \multirow{4}{*}{$\begin{array}{c}\text { BRAZIL } \\
\text { Piaui } \\
\text { Pedro II } \\
766\end{array}$} \\
\hline & $Q r$ & $Q r$ & $Q r$ & $Q r$ & $Q r$ & Jalisco & Jalisco & Jalisco & Nayarit & \\
\hline & $\mathrm{LaFe}$ & Guaca. & Iris & Carbo. & C.V. & Martin & Lupita & Lupita & Guaca. & \\
\hline & $747^{*}$ & 767B & 768B & 770 & $771^{*}$ & 769 & $772^{*}$ & $774^{*}$ & 765 & \\
\hline $\mathrm{SiO}_{2}$ & 76.75 & 78.94 & 77.13 & 77.86 & 79.49 & 76.62 & 76.46 & 75.96 & 79.06 & 96.26 \\
\hline $\mathrm{Al}_{2} \mathrm{O}_{3}$ & 11.38 & 10.83 & 12.26 & 11.42 & 12.21 & 13.99 & 14.36 & 11.06 & 10.52 & 1.33 \\
\hline $\mathrm{Fe}_{2} \mathrm{O}_{3}$ & 1.77 & 1.37 & 1.06 & 1.72 & 1.06 & 2.73 & 1.62 & 2.89 & 1.21 & 0.46 \\
\hline MgO & 0.28 & 0.07 & 0.09 & 0.10 & 0.09 & 0.11 & 0.09 & 0.07 & 0.08 & 0.07 \\
\hline $\mathrm{CaO}$ & 0.39 & 0.05 & 0.08 & 0.07 & 0.05 & 0.07 & 0.06 & 0.17 & 0.05 & 0.04 \\
\hline $\mathrm{Na}_{2} \mathrm{O}$ & 2.72 & 2.78 & 0.06 & 3.56 & 0.73 & 0.15 & 0.16 & 5.18 & 2.44 & 0.03 \\
\hline $\mathrm{K}_{2} \mathrm{O}$ & 4.13 & 4.22 & 0.14 & 4.83 & 1.29 & 0.53 & 0.07 & 4.36 & 4.42 & 0.01 \\
\hline $\mathrm{TiO}_{2}$ & 0.11 & 0.15 & 0.15 & 0.11 & 0.12 & 0.20 & 0.17 & 0.12 & 0.12 & 0.47 \\
\hline MnO & 0.01 & 0.00 & 0.00 & 0.01 & 0.01 & 0.01 & 0.00 & 0.05 & 0.00 & 0.03 \\
\hline $\mathbf{P}_{2} \mathbf{O}_{5}$ & 0.03 & 0.03 & 0.04 & 0.04 & 0.04 & 0.05 & 0.04 & 0.03 & 0.03 & 0.10 \\
\hline $\mathrm{H}_{2} \mathrm{O}+$ & 0.45 & 0.47 & 2.98 & 0.34 & 0.57 & 0.60 & 0.65 & 0.03 & 0.24 & 0.62 \\
\hline $\mathrm{H}_{2} \mathrm{O}-$ & 1.27 & 1.19 & 5.13 & 0.56 & 4.44 & 5.56 & 5.87 & 0.43 & 1.15 & 1.27 \\
\hline Total & 99.28 & 100.12 & 99.14 & 100.62 & 100.09 & 100.63 & 99.56 & 100.35 & 99.32 & 100.68 \\
\hline (ppm) & $747^{*}$ & 767B & 768B & 770 & $771^{*}$ & 769 & $772^{*}$ & 774 & 765 & 766 \\
\hline $\mathbf{R b}$ & 134.46 & 247.60 & 10.32 & 180.73 & 50.84 & 28.16 & 7.12 & 193.75 & 159.90 & 0.31 \\
\hline $\mathrm{Sr}$ & 4.25 & 3.10 & 8.72 & 6.65 & 6.51 & 17.79 & 5.21 & 0.25 & 2.82 & 4.30 \\
\hline$Y$ & 24.69 & 230.61 & 175.85 & 92.21 & 48.06 & 45.58 & 137.49 & 91.22 & 50.32 & 6.04 \\
\hline $\mathrm{Zr}$ & 387.14 & 1486.86 & 1488.13 & 506.67 & 533.84 & 800.76 & 1265.05 & 953.40 & 461.79 & 332.99 \\
\hline $\mathrm{Nb}$ & 23.92 & 71.43 & 71.53 & 26.20 & 32.54 & 67.23 & 101.37 & 72.96 & 35.47 & 4.99 \\
\hline $\mathrm{Ba}$ & 108.19 & 18.88 & 36.04 & 166.44 & 65.52 & 42.61 & 17.31 & 0.65 & 10.79 & 11.43 \\
\hline La & 9.83 & 2.56 & 31.76 & 70.69 & 14.81 & 44.88 & 26.45 & 53.53 & 17.87 & 10.11 \\
\hline $\mathrm{Ce}$ & 17.75 & 16.99 & 59.91 & 77.00 & 30.95 & 80.09 & 95.16 & 123.56 & 23.56 & 21.13 \\
\hline $\mathrm{Pr}$ & 1.99 & 1.46 & 9.53 & 19.12 & 5.69 & 8.79 & 7.55 & 15.41 & 3.95 & 2.29 \\
\hline $\mathbf{N d}$ & 7.39 & 8.84 & 35.14 & 61.49 & 25.03 & 26.91 & 37.12 & 60.65 & 15.42 & 8.14 \\
\hline $\mathrm{Sm}$ & 2.05 & 10.50 & 13.70 & 13.33 & 6.76 & 3.91 & 14.64 & 15.65 & 5.12 & 1.51 \\
\hline $\mathrm{Eu}$ & 0.27 & 0.43 & 0.65 & 1.01 & 0.46 & 0.19 & 0.48 & 0.31 & 0.17 & 0.18 \\
\hline Gd & 2.34 & 23.74 & 17.41 & 12.00 & 6.64 & 3.98 & 17.06 & 14.69 & 6.14 & 1.07 \\
\hline $\mathrm{Tb}$ & 0.59 & 6.35 & 4.57 & 2.55 & 1.43 & 0.96 & 3.37 & 2.73 & 1.28 & 0.17 \\
\hline Dy & 5.00 & 43.97 & 34.42 & 17.23 & 10.17 & 7.78 & 22.49 & 17.63 & 8.80 & 1.09 \\
\hline Ho & 1.30 & 9.25 & 7.74 & 3.65 & 2.28 & 1.90 & 4.91 & 3.70 & 1.95 & 0.24 \\
\hline $\mathrm{Er}$ & 4.30 & 25.04 & 22.47 & 10.22 & 6.76 & 5.88 & 13.89 & 10.37 & 5.48 & 0.73 \\
\hline $\mathrm{Tm}$ & 0.70 & 3.44 & 3.31 & 1.45 & 1.02 & 0.88 & 1.94 & 1.46 & 0.80 & 0.11 \\
\hline $\mathrm{Yb}$ & 5.35 & 22.60 & 22.49 & 9.67 & 7.17 & 6.07 & 13.09 & 9.90 & 5.65 & 0.88 \\
\hline Lu & 0.86 & 3.36 & 3.33 & 1.46 & 1.12 & 0.94 & 2.05 & 1.55 & 0.87 & 0.14 \\
\hline $\mathrm{Hf}$ & 11.43 & 38.30 & 37.98 & 13.64 & 15.16 & 20.15 & 30.49 & 24.38 & 12.35 & 8.35 \\
\hline $\mathrm{Ta}$ & 1.87 & 5.36 & 5.26 & 2.17 & 2.54 & 4.98 & 7.65 & 5.96 & 2.66 & 1.35 \\
\hline $\mathrm{Pb}$ & 22.19 & 11.69 & 23.14 & 12.03 & 11.57 & 18.20 & 24.93 & 31.41 & 21.34 & 7.17 \\
\hline Th & 14.88 & 41.83 & 41.71 & 19.33 & 18.59 & 22.04 & 32.64 & 24.70 & 14.51 & 6.20 \\
\hline $\mathbf{U}$ & 3.30 & 11.75 & 6.16 & 2.95 & 3.49 & 2.57 & 6.57 & 7.79 & 4.55 & 2.84 \\
\hline
\end{tabular}


Table 3. Instrumental and data acquisition parameters for ICP-MS using an Agilent Technologies HP4500.

\begin{tabular}{ll}
\hline & NormalPlasma \\
\hline RF Power & $1360 \mathrm{~W}$ \\
Plasma gas & $15 \mathrm{~L} / \mathrm{min}$ \\
Auxiliary gas & $1.0 \mathrm{~L} / \mathrm{min}$ \\
Carrier gas & $1.13 \mathrm{~L} / \mathrm{min}$ \\
Nebulizer & Cross-flow \\
Spray Chamber $\mathrm{T}^{\circ}$ & $2^{\circ} \mathrm{C}$ \\
& \\
Quantitative analysis $^{+}$ & $3 \mathrm{sec} /$ mass \\
$\mathrm{CeO}^{+} / \mathrm{Ce}^{+}$ & $0.6 \%$ \\
$\mathrm{Ce}^{++} / \mathrm{Ce}^{+}$ & $1 \%$ \\
\hline
\end{tabular}


Table 4. Impurity and trace element content (ppm) in opals determined by ICP-MS. (D.1.. detection limits; n.d.. non detected; n.s.. non standardized).

\begin{tabular}{|c|c|c|c|c|c|c|c|c|c|c|c|c|c|c|c|c|c|c|c|c|c|}
\hline & $\mathrm{Na}$ & Mg & $\mathrm{Al}$ & $\mathbf{K}$ & $\mathrm{Ca}$ & Sc & $\mathrm{Ti}$ & $\mathbf{V}$ & $\mathrm{Cr}$ & Mn & $\mathrm{Fe}$ & Co & $\mathrm{Ni}$ & $\mathrm{Cu}$ & $\mathrm{Zn}$ & As & $\mathbf{R b}$ & $\mathrm{Sr}$ & $\mathbf{Y}$ & $\mathbf{Z r}$ & Nb \\
\hline \multicolumn{22}{|l|}{ PERU } \\
\hline 620 & 406 & 7447 & 514 & 113 & 491 & 0.06 & n.d. & 20.69 & 0.36 & 0.37 & 181.7 & 0.06 & 4.73 & 7139.68 & 168.49 & 0.46 & 0.49 & 2.03 & 0.31 & n.d. & n.d. \\
\hline QOP3 & 121 & 35755 & 24041 & 780 & 818 & 0.19 & 232.72 & 23.47 & 0.27 & 780.30 & 2482.5 & 21.43 & 6.46 & 31.29 & 13.36 & 0.51 & 3.93 & 5.59 & 0.87 & 3.80 & 1.01 \\
\hline \multirow{2}{*}{\multicolumn{22}{|c|}{ MEXICO }} \\
\hline & & & & & & & & & & & & & & & & & & & & & \\
\hline 643 & 135 & 22891 & 14373 & 61 & 490 & 0.15 & 41.58 & 30.69 & 0.12 & 154.69 & 434.7 & 5.61 & 4.12 & 44.73 & 20.94 & 0.21 & 0.40 & 3.03 & 0.17 & 3.63 & 0.50 \\
\hline 267 & 68 & 8797 & 4034 & 22 & 348 & 0.01 & n.d. & 11.72 & 0.42 & 22.95 & 23.4 & 0.19 & 2.79 & 31.61 & 16.80 & n.d. & 0.08 & 1.87 & 0.03 & n.d. & n.d. \\
\hline \multirow[t]{2}{*}{267} & 74 & 7621 & 2907 & 11 & 317 & 0.01 & n.d. & 13.52 & 0.14 & 12.69 & 22.6 & 0.13 & 1.06 & 22.24 & 10.88 & n.d. & 0.02 & 1.45 & 0.01 & n.d. & n.d. \\
\hline & \multicolumn{21}{|c|}{ Queretaro } \\
\hline 799 & 44 & 99 & 1493 & 445 & 199 & 0.43 & 2.78 & 0.38 & 0.13 & 0.66 & 189.6 & 0.09 & 0.11 & 0.65 & 1.03 & 0.03 & 4.47 & 6.44 & 3.39 & 62.12 & 0.11 \\
\hline 730 & 471 & 84 & 947 & 100 & 191 & 0.08 & 1.01 & 0.00 & 0.01 & 0.26 & 16.2 & 0.01 & 0.08 & 0.20 & 2.59 & 0.00 & 1.64 & 0.84 & 2.60 & 4.77 & 0.14 \\
\hline 801 & 348 & 11 & 1225 & 1014 & 57 & 0.02 & 29.40 & 0.03 & 0.02 & 2.77 & 220.8 & 0.04 & 0.09 & 0.16 & 6.26 & 0.00 & 16.32 & 0.49 & 4.78 & 12.09 & 2.14 \\
\hline $767 B$ & 225 & 12 & 1252 & 996 & 70 & 0.02 & 17.34 & 0.05 & 0.02 & 10.95 & 399.2 & 0.07 & 0.08 & 1.32 & 25.58 & 0.00 & 11.95 & 0.52 & 6.51 & 20.04 & 1.33 \\
\hline $768 A$ & 158 & 28 & 802 & 259 & 259 & 0.01 & 2.06 & 0.09 & 0.06 & 0.81 & 71.6 & 0.01 & 0.29 & 0.10 & 1.14 & 0.03 & 2.79 & 2.14 & 1.38 & 12.59 & 3.70 \\
\hline $768 B$ & 76 & 1 & 257 & 192 & 0 & 0.01 & 1.94 & 0.01 & 0.01 & 0.98 & 25.5 & 0.00 & 0.22 & 0.07 & 6.81 & 0.00 & 2.33 & 0.03 & 0.66 & 8.97 & 0.23 \\
\hline 770 & 698 & 25 & 1412 & 465 & 110 & 0.03 & 18.60 & 0.02 & 0.01 & 2.27 & 549.3 & 0.00 & 0.13 & 0.35 & 7.24 & 0.00 & 6.28 & 0.47 & 10.04 & 20.04 & 1.94 \\
\hline 771 & 193 & 77 & 1470 & 658 & 352 & 0.01 & 0.86 & 0.01 & 0.01 & 1.55 & 24.7 & 0.01 & 0.02 & 0.04 & 1.80 & 0.00 & 7.19 & 4.89 & 2.39 & 10.15 & 0.07 \\
\hline 626 & 412 & 2 & 1356 & 1027 & 50 & 0.02 & n.d. & 0.01 & 0.00 & 0.51 & 9.0 & 0.00 & 0.24 & 0.05 & 5.45 & 0.00 & 9.95 & 0.31 & 13.94 & n.d. & n.d. \\
\hline 627 & 488 & 38 & 1880 & 1081 & 389 & 0.04 & n.d. & 0.02 & 0.01 & 3.00 & 128.5 & 0.01 & 0.22 & 0.08 & 14.55 & 0.01 & 13.35 & 3.92 & 15.75 & n.d. & n.d \\
\hline 628 & 398 & 9 & 1344 & 961 & 51 & 0.17 & n.d. & 0.12 & 0.46 & 4.73 & 866.0 & 0.01 & 1.14 & 0.64 & 12.71 & 1.37 & 9.45 & 0.35 & 18.65 & n.d. & n.d. \\
\hline 798 & 169 & 76 & 1503 & 933 & 331 & 0.15 & 39.10 & 0.29 & 0.03 & 1.79 & 413.4 & 0.01 & 1.14 & 0.21 & 2.49 & 11.74 & 5.63 & 4.67 & 8.60 & 40.80 & 1.69 \\
\hline \multirow[t]{2}{*}{747} & 21 & 23 & 159 & 50 & 73 & 0.01 & 0.09 & 0.27 & 0.02 & 0.04 & 4.0 & 0.00 & 0.04 & 0.03 & 0.44 & 0.00 & 0.36 & 0.73 & 0.06 & 0.77 & 0.01 \\
\hline & \multicolumn{21}{|c|}{ Jalisco } \\
\hline$J A L 2 S$ & 69 & 35 & 821 & 472 & 92 & 0.06 & 11.60 & 0.25 & 0.04 & 8.16 & 435.1 & 0.00 & 0.13 & 0.08 & 0.92 & 0.34 & 6.87 & 1.75 & 1.15 & 28.80 & 1.32 \\
\hline$J A L 2 D$ & 80 & 51 & 785 & 372 & 141 & 0.07 & 14.79 & 0.35 & 0.08 & 6.35 & 526.2 & 0.00 & 0.32 & 0.08 & 33.98 & 0.02 & 4.87 & 3.10 & 0.99 & 29.31 & 1.39 \\
\hline 800 & 98 & 74 & 1611 & 1246 & 264 & 0.22 & 2.40 & 0.04 & 0.02 & 14.11 & 48.6 & 0.01 & 0.07 & 0.05 & 1.14 & 0.02 & 11.30 & 2.36 & 0.70 & 6.18 & 0.00 \\
\hline $629 A$ & 126 & 38 & 833 & 494 & 106 & 0.04 & n.d. & 0.01 & 0.03 & 5.30 & 258.6 & 0.00 & 0.47 & 0.16 & 0.42 & 0.00 & 6.55 & 2.94 & 1.92 & n.d. & \\
\hline $629 B$ & 93 & 46 & 1026 & 561 & 130 & 0.06 & n.d. & 0.00 & 0.04 & 7.17 & 340.2 & 0.00 & 0.33 & 0.23 & 0.84 & 0.00 & 8.51 & 3.71 & 2.48 & n.d. & n.d \\
\hline 630 & 120 & 106 & 1220 & 547 & 165 & 0.18 & n.d. & 0.71 & 0.35 & 9.03 & 791.8 & 0.04 & 0.29 & 0.53 & 6.55 & 0.00 & 8.71 & 5.08 & 9.17 & n.d. & n.d. \\
\hline 772 & 120 & 9 & 814 & 685 & 115 & 0.06 & 4.01 & 0.05 & 0.06 & 5.62 & 20.8 & 0.01 & 0.03 & 0.10 & 2.87 & 0.00 & 7.11 & 1.23 & 4.36 & 14.74 & 1.30 \\
\hline 774 & 347 & 20 & 1396 & 616 & 156 & 0.09 & 7.66 & 0.03 & 0.01 & 5.88 & 180.7 & 0.01 & 0.03 & 0.03 & 0.65 & 0.01 & 4.99 & 1.16 & 1.41 & 55.80 & 0.68 \\
\hline 773 & 123 & 61 & 1136 & 614 & 225 & 0.16 & 5.10 & 0.05 & 0.00 & 12.56 & 8.8 & 0.01 & 0.07 & 0.07 & 1.25 & 0.00 & 6.93 & 2.08 & 2.06 & 9.43 & 0.22 \\
\hline 769 & 257 & 247 & 48174 & 1212 & 424 & 2.74 & 564.65 & 4.92 & 1.70 & 15.66 & 11041.2 & 0.35 & 0.91 & 8.10 & 36.59 & 2.24 & 16.42 & 12.18 & 36.44 & 377.89 & 31.99 \\
\hline \multirow[t]{2}{*}{631} & 175 & 220 & 68202 & 763 & 371 & 2.41 & n.d. & 6.39 & 2.40 & 25.98 & 13802.4 & 0.38 & 2.17 & 11.43 & 45.71 & 1.21 & 12.09 & 11.87 & 40.93 & n.d. & n.d \\
\hline & \multicolumn{21}{|c|}{ Nayarit } \\
\hline 765 & 155 & 22 & 1125 & 812 & 80 & 0.01 & 1.78 & 0.00 & 0.01 & 9.48 & 340.0 & 0.01 & 0.04 & 0.16 & 1.67 & 0.10 & 7.25 & 1.21 & 1.06 & 7.15 & 0.18 \\
\hline $623 A$ & 392 & 19 & 3034 & 2295 & 130 & 0.33 & n.d. & 0.29 & 0.08 & 29.96 & 4838.8 & 0.01 & 1.19 & 0.24 & 12.22 & 3.32 & 17.94 & 0.72 & 15.94 & n.d. & n.d. \\
\hline $623 B$ & 395 & 18 & 2964 & 2335 & 129 & 0.37 & n.d. & 0.35 & 0.05 & 31.75 & 5472.7 & 0.01 & 4.25 & 4.20 & 14.03 & 3.69 & 19.68 & 0.54 & 17.23 & n.d. & n.d. \\
\hline 624 & 415 & 7 & 1719 & 829 & 77 & 0.11 & n.d. & 0.01 & 0.00 & 17.38 & 869.1 & 0.00 & 0.26 & 0.05 & 1.63 & 0.26 & 6.97 & 0.35 & 3.08 & n.d. & n.d. \\
\hline 625 & 43 & 103 & 2682 & 918 & 430 & 0.02 & n.d. & 0.21 & 0.18 & 0.14 & 13.3 & 0.00 & 0.64 & 0.14 & 3.00 & 0.00 & 27.45 & 11.28 & 15.93 & n.d. & n.d. \\
\hline
\end{tabular}

\section{ETHIOPIA}

\begin{tabular}{|c|c|c|c|c|c|c|c|c|c|c|c|c|c|c|c|c|c|c|c|c|c|}
\hline 580 & 378 & 405 & 8720 & 1104 & 5062 & 0.38 & 222.47 & 0.22 & 0.05 & 63.93 & 3192.7 & 0.19 & 0.24 & 0.36 & 12.38 & 1.75 & 7.67 & 47.26 & 15.09 & 115.55 & 37.36 \\
\hline 581 & 153 & 108 & 2972 & 463 & 1675 & 0.12 & 23.90 & 0.06 & 0.01 & 7.76 & 254.3 & 0.01 & 0.03 & 0.34 & 1.01 & 0.08 & 3.36 & 10.88 & 4.98 & 49.61 & 9.41 \\
\hline 726 & 552 & 144 & 7134 & 1519 & 4076 & 0.08 & 7.26 & 1.54 & 0.00 & 0.12 & 13.8 & 0.01 & 0.04 & 0.08 & 0.27 & 0.04 & 17.43 & 38.03 & 7.75 & 68.98 & 15.82 \\
\hline 727 & 462 & 146 & 13849 & 2964 & 8338 & 0.09 & 3.30 & 0.55 & 0.01 & 0.18 & 27.1 & 0.03 & 0.14 & 0.13 & 0.23 & 0.00 & 46.99 & 97.29 & 2.07 & 57.33 & 22.49 \\
\hline 584 & 56 & 9 & 469 & 84 & 266 & 0.01 & 0.77 & 0.07 & 0.00 & 0.02 & 0.0 & 0.00 & 0.11 & 0.03 & 0.26 & 0.00 & 0.57 & 1.66 & 0.88 & 10.95 & 2.05 \\
\hline 617 & 1124 & 72 & 3267 & 582 & 1304 & 0.13 & n.d. & 0.01 & 0.08 & 25.22 & 1573.3 & 0.03 & 0.42 & 0.10 & 3.01 & 0.08 & 2.81 & 10.52 & 3.09 & n.d. & n.d. \\
\hline 618 & 689 & 64 & 4090 & 1811 & 1565 & 0.03 & n.d. & 0.02 & 0.02 & 4.40 & 21.5 & 0.01 & 0.02 & 0.03 & 0.12 & 0.00 & 5.94 & 13.92 & 3.13 & n.d. & n.d. \\
\hline 619 & 380 & 568 & 13773 & 1759 & 6010 & 0.12 & n.d. & 0.04 & 0.09 & 3.84 & 81.0 & 0.17 & 0.75 & 3.24 & 6.22 & 0.59 & 17.28 & 70.17 & 1.60 & n.d. & n.d. \\
\hline
\end{tabular}

\section{HONDURAS}

\begin{tabular}{|c|c|c|c|c|c|c|c|c|c|c|c|c|c|c|c|c|c|c|c|c|c|}
\hline $632 A$ & 87 & 122 & 2455 & 602 & 898 & 0.19 & n.d. & 0.04 & 0.01 & 0.03 & 10.5 & 0.00 & 1.26 & 0.11 & 0.47 & 0.01 & 6.16 & 0.76 & 0.01 & n.d. & n.d. \\
\hline $632 B$ & 119 & 174 & 3167 & 726 & 1073 & 0.19 & n.d. & 0.04 & 0.02 & 0.31 & 10.4 & 0.00 & 0.18 & 0.05 & 0.33 & 0.01 & 7.12 & 2.44 & 0.12 & n.d. & n.d. \\
\hline 633 & 123 & 458 & 5759 & 1099 & 1878 & 0.25 & n.d. & 0.02 & 0.02 & 0.29 & 6.6 & 0.00 & 0.76 & 0.11 & 0.32 & 0.01 & 11.28 & 1.82 & 0.11 & n.d. & n.d. \\
\hline 634 & 246 & 126 & 3811 & 1157 & 1105 & 0.15 & n.d. & 0.09 & 0.01 & 0.46 & 60.2 & 0.01 & 5.47 & 0.03 & 0.58 & 0.04 & 9.15 & 0.93 & 0.07 & n.d. & n.d. \\
\hline 635 & 433 & 35 & 2596 & 1094 & 702 & 0.04 & n.d. & 0.05 & 0.01 & 0.14 & 19.6 & 0.00 & 0.40 & 0.03 & 0.27 & 0.00 & 5.10 & 0.37 & 0.04 & n.d. & n.d. \\
\hline 787 & 15 & 7 & 150 & 112 & 28 & 0.01 & 0.20 & 0.49 & 0.03 & 0.06 & 0.0 & 0.00 & 0.14 & 0.04 & 0.10 & 0.00 & 0.72 & 0.85 & 0.05 & 0.01 & 0.00 \\
\hline 791 & 6 & 5 & 98 & 59 & 22 & 0.02 & 0.15 & 0.10 & 0.06 & 0.02 & 0.0 & 0.00 & 0.05 & 0.04 & 0.07 & 0.02 & 0.40 & 0.75 & 0.04 & 0.03 & 0.00 \\
\hline
\end{tabular}

BRAZIL

$\begin{array}{lccccccccccccccccccccc}621 & 78 & 423 & 1659 & 167 & 377 & 2.04 & \text { n.d. } & 73.69 & 13.35 & 4.85 & 2033.5 & 0.02 & 1.16 & 3.36 & 12.33 & 0.00 & 0.81 & 2.63 & 14.25 & \text { n.d. } & \text { n.d. } \\ 622 & 41 & 78 & 1173 & 376 & 513 & 0.41 & \text { n.d. } & 0.05 & 0.11 & 0.64 & 69.3 & 0.02 & 0.43 & 0.04 & 0.45 & 0.02 & 4.39 & 3.79 & 0.07 & \text { n.d. } & \text { n.d. }\end{array}$ $\begin{array}{lllllllllllllllllllllll}761 & 67 & 104 & 781 & 146 & 267 & 0.02 & 0.18 & 0.06 & 0.08 & 0.12 & 28.7 & 0.01 & 0.20 & 0.02 & 0.28 & 0.01 & 2.34 & 1.06 & 0.05 & 2.75 & 0.05\end{array}$ $\begin{array}{llllllllllllllllllllll}762 & 83 & 146 & 1200 & 142 & 330 & 0.14 & 0.31 & 0.04 & 0.11 & 1.60 & 31.8 & 0.66 & 0.68 & 0.08 & 1.82 & 0.01 & 3.61 & 1.81 & 0.33 & 2.25 & 0.05\end{array}$

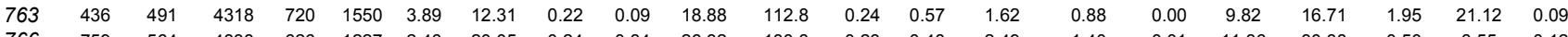
$\begin{array}{lllllllllllllll}766 & 759 & 564 & 4838 & 626 & 1227 & 2.46 & 20.05 & 0.24 & 0.34 & 26.32 & 180.8 & 0.23 & 0.48 & 2.49\end{array}$

AUSTRALIA

$\begin{array}{lllllllllllllll}827 & 783 & 227 & 6931 & 1342 & 1664 & 0.61 & 77.09 & 0.58 & 0.16 & 21.33 & 648.0 & 2.41 & 2.01 & 5.47\end{array}$ $\begin{array}{lllllllllllllll}234 & 1433 & 288 & 7449 & 1619 & 2152 & 0.59 & \text { n.d. } & 0.73 & 0.26 & 19.07 & 791.6 & 1.01 & 0.95 & 4.29\end{array}$ $\begin{array}{lllllllllllllll}234 & 998 & 267 & 6656 & 1287 & 2021 & 0.47 & \text { n.d. } & 0.32 & 0.18 & 17.58 & 724.9 & 0.36 & 0.43 & 1.29\end{array}$ $\begin{array}{lllllllllllllll}847 & 789 & 196 & 5754 & 2189 & 1023 & 0.20 & 2.47 & 0.08 & 0.06 & 12.27 & 379.6 & 0.10 & 0.24 & 0.25\end{array}$ $\begin{array}{lllllllllllllll}832 & 1506 & 261 & 9122 & 1350 & 3824 & 0.23 & 6.99 & 0.10 & 0.04 & 11.54 & 786.1 & 0.06 & 0.09 & 0.22\end{array}$ $\begin{array}{lllllllllllllll}835 & 679 & 147 & 6292 & 1527 & 1869 & 0.32 & 18.75 & 0.27 & 0.05 & 5.47 & 298.9 & 0.17 & 0.16 & 0.23\end{array}$

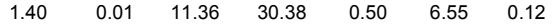

$\begin{array}{lllllll}0.69 & 0.39 & 11.92 & 47.18 & 1.35 & 161.33 & 0.26\end{array}$

$\begin{array}{llllll}1.70 & \text { n.d. } 13.98 & 64.45 & 1.68 & \text { n.d. } & \text { n.d. }\end{array}$ $0.55 \quad$ n.d. $12.65 \quad 55.95 \quad 0.84 \quad$ n.d. $\quad$ n.d. $\begin{array}{lllllll}0.61 & 0.05 & 27.15 & 43.60 & 0.58 & 17.66 & 0.00\end{array}$ $\begin{array}{lllllll}1.17 & 0.00 & 12.13 & 44.27 & 1.16 & 54.61 & 0.00\end{array}$ $\begin{array}{lllllll}0.41 & 0.04 & 15.90 & 184.97 & 0.69 & 104.30 & 0.06\end{array}$

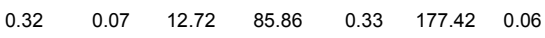


$\begin{array}{llllllllllllllllllllll}844 & 1444 & 442 & 9735 & 3261 & 2255 & 0.14 & 26.33 & 0.34 & 0.13 & 30.44 & 328.4 & 0.66 & 0.98 & 3.07 & 3.55 & 0.21 & 16.35 & 99.81 & 3.57 & 50.81 & 0.26\end{array}$

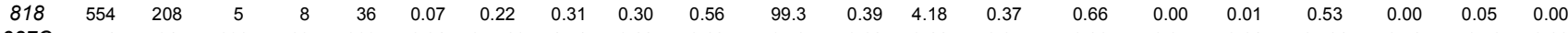

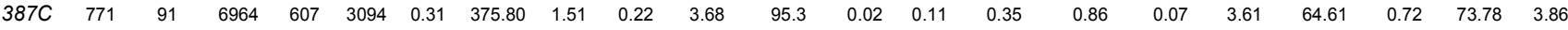

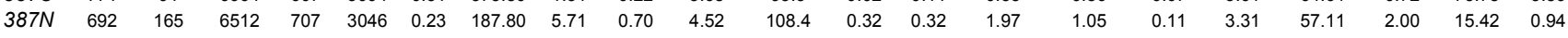

SLOVAKIA

$\begin{array}{lllllllllllllllllllllll}204.2 & 80 & 255 & 7506 & 899 & 1635 & 1.14 & 8.39 & 0.11 & 0.04 & 13.31 & 1090.7 & 0.77 & 0.28 & 0.21 & 2.39 & 0.08 & 19.60 & 18.25 & 4.12 & 1.03 & 0.11\end{array}$ $\begin{array}{llllllllllllllllllllll}650 & 41 & 279 & 1989 & 356 & 820 & 0.25 & 58.83 & 8.67 & 1.97 & 2.30 & 1136.9 & 0.04 & 0.29 & 0.30 & 0.88 & 11.78 & 3.87 & 7.61 & 0.86 & 4.85 & 0.32\end{array}$

KAZAKHSTAN

$\begin{array}{llllllllllllllllllllllll}107 & 246 & 255 & 1462 & 236 & 354 & 0.90 & 2.26 & 0.18 & 1.57 & 1.67 & 247.7 & 0.20 & 3.01 & 1.27 & 2.21 & 0.34 & 6.53 & 31.20 & 4.00 & 1.27 & 0.00\end{array}$

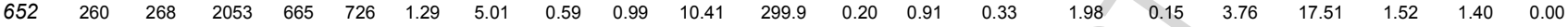

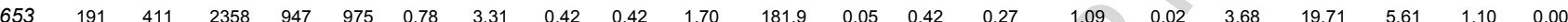

TANZANIA

$\begin{array}{llllllllllllllllllllll}793 & 15 & 961 & 93 & 7 & 306 & 0.03 & 8.28 & 2.95 & 0.35 & 0.92 & 1900.4 & 0.00 & 0.80 & 0.91 & 3.07 & 0.02 & 0.03 & 0.64 & 0.07 & 1.23 & 0.19\end{array}$ $\begin{array}{llllllllllllllllllllll}794 & 31 & 1466 & 2853 & 128 & 719 & 0.95 & 76.10 & 1.16 & 0.47 & 2.40 & 6301.4 & 2.41 & 3.12 & 9.00 & 122.21 & 0.01 & 1.24 & 4.19 & 4.50 & 6.53 & 0.15\end{array}$

USA

$\begin{array}{llllllllllllllllllllll}95 & 629 & 15 & 1989 & 890 & 514 & 0.34 & 1.70 & 0.17 & 0.05 & 0.87 & 6.5 & 0.00 & 0.17 & 0.10 & 0.17 & 0.07 & 24.76 & 7.19 & 4.72 & 6.72 & 0.54\end{array}$

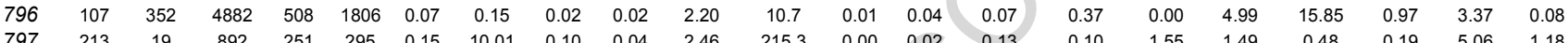
\begin{tabular}{lllllllllllllllllllllllll} 
D.I. & 1.03 & 0.02 & 0.02 & 380 & 3.75 & n.s. & n.s. & n.s. & 0.03 & 0.02 & 10.13 & n.s. & n.s. & 0.006 & 0.01 & n.s. & 0.004 & 0.0004 & n.s. & n.s. & n.s. \\
\hline
\end{tabular}

\begin{tabular}{|c|c|c|c|c|c|c|c|c|c|c|c|c|c|c|c|c|c|c|c|c|}
\hline & Cd & Cs & $\mathrm{Ba}$ & La & $\mathrm{Ce}$ & $\mathrm{Pr}$ & Nd & Sm & Eu & Gd & Tb & Dy & Ho & Er & $\mathrm{Tm}$ & Yb & Lu & $\mathrm{Pb}$ & Th & $\mathbf{U}$ \\
\hline & & & & & & & & & & & & & & & & & & & & \\
\hline 620 & 3.64 & 0.38 & 0.47 & 0.337 & 0.442 & 0.073 & 0.304 & 0.059 & 0.008 & 0.053 & 0.007 & 0.046 & 0.010 & 0.032 & 0.005 & 0.042 & 0.009 & 0.23 & 0.03 & 31.77 \\
\hline
\end{tabular}

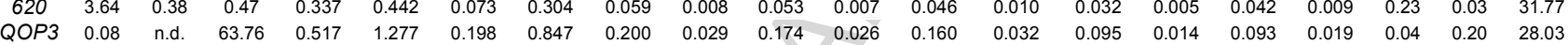

\section{MEXICO}

\section{Durango}

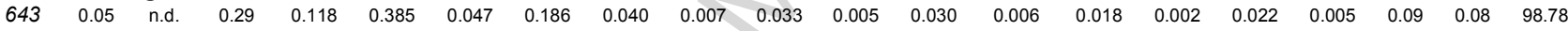

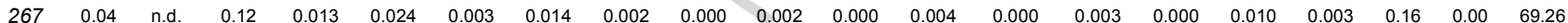
$\begin{array}{lllllllllllllllllllll}267 & 0.02 & \text { n.d. } & 0.03 & 0.003 & 0.004 & 0.001 & 0.004 & 0.001 & 0.000 & 0.000 & 0.000 & 0.001 & 0.000 & 0.001 & 0.000 & 0.006 & 0.002 & 0.03 & 0.00 & 130.72\end{array}$

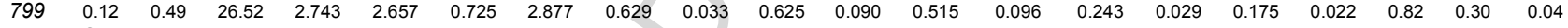

Queretaro

$\begin{array}{lllllllllllllllllllll}730 & 0.02 & \text { n.d. } & 1.88 & 1.672 & 5.056 & 0.583 & 2.255 & 0.562 & 0.025 & 0.483 & 0.082 & 0.517 & 0.096 & 0.273 & 0.038 & 0.241 & 0.033 & 0.33 & 0.32 & 1.60\end{array}$

$\begin{array}{lllllllllllllllllllll}801 & 0.01 & 0.67 & 0.75 & 2.817 & 5.007 & 1.071 & 4.264 & 1.119 & 0.021 & 0.938 & 0.138 & 0.800 & 0.139 & 0.364 & 0.045 & 0.252 & 0.033 & 1.89 & 0.57 & 0.17\end{array}$

$\begin{array}{lllllllllllllllllllll}767 B & 0.03 & \text { n.d. } & 1.87 & 2.643 & 4.686 & 0.989 & 4.034 & 1.145 & 0.025 & 1.187 & 0.195 & 1.113 & 0.208 & 0.533 & 0.064 & 0.356 & 0.050 & 2.67 & 0.50 & 0.30\end{array}$

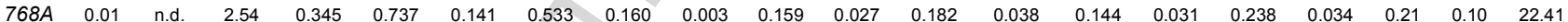

$\begin{array}{llllllllllllllllllllll}768 B & 0.00 & \text { n.d. } & 0.13 & 0.668 & 1.177 & 0.258 & 0.958 & 0.219 & 0.005 & 0.168 & 0.023 & 0.121 & 0.021 & 0.055 & 0.007 & 0.041 & 0.005 & 0.27 & 0.12 & 0.13\end{array}$

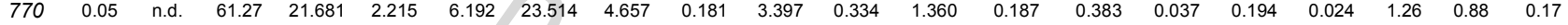

$\begin{array}{lllllllllllllllllllll}771 & 0.01 & \text { n.d. } & 51.66 & 0.744 & 2.775 & 0.462 & 2.221 & 0.520 & 0.020 & 0.479 & 0.057 & 0.293 & 0.050 & 0.118 & 0.013 & 0.074 & 0.009 & 0.06 & 0.05 & 0.16\end{array}$

$\begin{array}{lllllllllllllllllllll}626 & 0.02 & 1.00 & 21.67 & 78.874 & 4.074 & 20.330 & 70.639 & 9.587 & 0.274 & 4.919 & 0.370 & 1.522 & 0.215 & 0.486 & 0.045 & 0.239 & 0.031 & 0.20 & 0.09 & 0.35\end{array}$

$\begin{array}{lllllllllllllllllllll}627 & 0.08 & 1.77 & 87.16 & 39.900 & 6.289 & 7.575 & 28.328 & 3.986 & 0.153 & 3.322 & 0.367 & 1.947 & 0.358 & 0.927 & 0.114 & 0.654 & 0.086 & 0.64 & 0.99 & 0.34\end{array}$

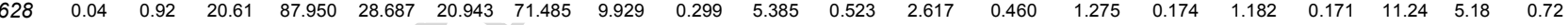

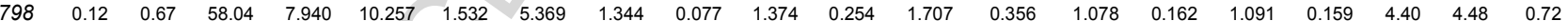

$\begin{array}{lllllllllllllllllllll}747 & 0.00 & \text { n.d. } & 2.33 & 0.016 & 0.020 & 0.006 & 0.028 & 0.008 & 0.000 & 0.008 & 0.001 & 0.010 & 0.001 & 0.005 & 0.000 & 0.006 & 0.000 & 0.01 & 0.03 & 0.78\end{array}$ Jalisco

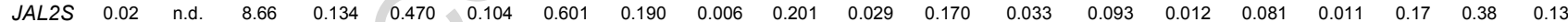
$\begin{array}{llllllllllllllllllllll}\text { JAL2D } & 0.02 & \text { n.d. } & 8.91 & 0.086 & 0.365 & 0.068 & 0.404 & 0.142 & 0.005 & 0.156 & 0.024 & 0.151 & 0.030 & 0.089 & 0.013 & 0.088 & 0.012 & 0.29 & 0.45 & 0.12\end{array}$ $\begin{array}{llllllllllllllllllllll}800 & 0.10 & 1.40 & 11.59 & 0.433 & 0.651 & 0.212 & 1.045 & 0.261 & 0.032 & 0.222 & 0.024 & 0.115 & 0.017 & 0.043 & 0.005 & 0.032 & 0.004 & 0.19 & 0.09 & 0.24\end{array}$

$\begin{array}{llllllllllllllllllllll}629 A & 0.01 & 0.53 & 34.81 & 1.066 & 4.621 & 1.008 & 4.772 & 0.972 & 0.025 & 0.667 & 0.064 & 0.264 & 0.034 & 0.066 & 0.006 & 0.032 & 0.003 & 0.04 & 0.02 & 0.21\end{array}$

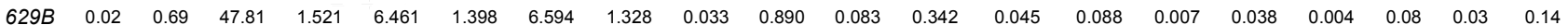

$\begin{array}{llllllllllllllllllllll}630 & 0.03 & 0.67 & 44.39 & 2.287 & 7.497 & 1.457 & 7.636 & 2.251 & 0.068 & 2.022 & 0.278 & 1.499 & 0.261 & 0.660 & 0.082 & 0.473 & 0.063 & 1.37 & 1.29 & 0.44\end{array}$

$\begin{array}{lllllllllllllllllllllll}772 & 0.02 & \text { n.d. } & 3.48 & 3.164 & 2.572 & 1.021 & 4.109 & 0.964 & 0.016 & 0.885 & 0.126 & 0.707 & 0.126 & 0.333 & 0.043 & 0.257 & 0.034 & 0.62 & 0.60 & 1.10\end{array}$

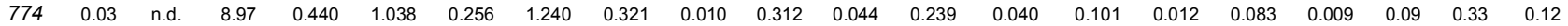

$\begin{array}{llllllllllllllllllllll}773 & 0.01 & \text { n.d. } & 10.19 & 0.221 & 0.749 & 0.214 & 1.260 & 0.411 & 0.057 & 0.413 & 0.058 & 0.326 & 0.059 & 0.158 & 0.021 & 0.129 & 0.018 & 0.14 & 0.16 & 0.22\end{array}$

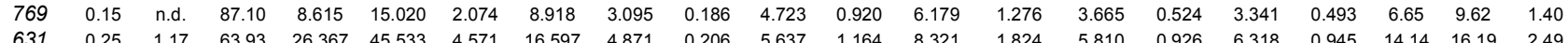

\section{Nayarit}

$\begin{array}{lllllllllllllllllllll}765 & 0.01 & \text { n.d. } & 1.53 & 1.646 & 1.607 & 0.429 & 1.787 & 0.328 & 0.008 & 0.268 & 0.031 & 0.160 & 0.029 & 0.072 & 0.008 & 0.050 & 0.007 & 0.44 & 0.16 & 0.18\end{array}$

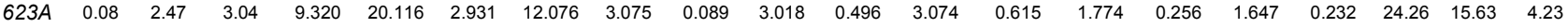

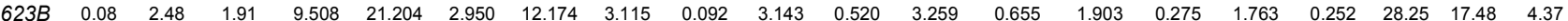
$\begin{array}{llllllllllllllllllllll}624 & 0.02 & 1.89 & 0.61 & 2.475 & 4.412 & 0.576 & 2.332 & 0.532 & 0.015 & 0.559 & 0.083 & 0.496 & 0.096 & 0.261 & 0.035 & 0.226 & 0.032 & 1.92 & 1.17 & 0.72\end{array}$

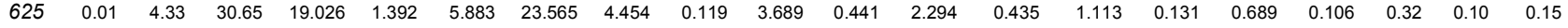

\section{ETHIOPIA}

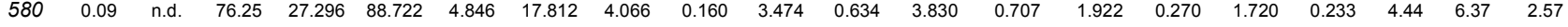

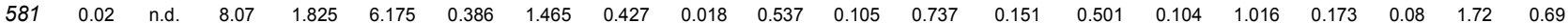

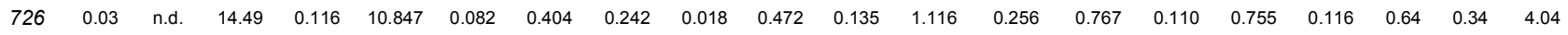
$\begin{array}{llllllllllllllllllllll}727 & 0.02 & \text { n.d. } & 92.51 & 0.060 & 0.420 & 0.023 & 0.107 & 0.060 & 0.000 & 0.129 & 0.031 & 0.266 & 0.057 & 0.196 & 0.033 & 0.252 & 0.039 & 0.04 & 0.23 & 0.95 \\ 584 & 0.01 & \text { n.d. } & 1.25 & 0.006 & 0.108 & 0.003 & 0.016 & 0.010 & 0.000 & 0.023 & 0.008 & 0.090 & 0.026 & 0.139 & 0.037 & 0.306 & 0.044 & 0.11 & 0.08 & 22.99\end{array}$ $\begin{array}{llllllllllllllllllllll}617 & 0.02 & 0.17 & 18.39 & 2.851 & 15.555 & 0.546 & 1.969 & 0.506 & 0.020 & 0.469 & 0.108 & 0.768 & 0.154 & 0.478 & 0.084 & 0.712 & 0.116 & 11.46 & 2.09 & 4.21 \\ 6 & 0.01 & 0.23 & 19.10 & 0.091 & 1.173 & 0.044 & 0.189 & 0.103 & 0.006 & 0.183 & 0.048 & 0.412 & 0.091 & 0.329 & 0.070 & 0.675 & 0.120 & 0.07 & 0.17 & 3.56\end{array}$ $\begin{array}{llllllllllllllllllllll}618 & 0.01 & 0.23 & 19.10 & 0.091 & 1.173 & 0.044 & 0.189 & 0.103 & 0.006 & 0.183 & 0.048 & 0.412 & 0.091 & 0.329 & 0.070 & 0.675 & 0.120 & 0.07 & 0.17 & 3.56\end{array}$

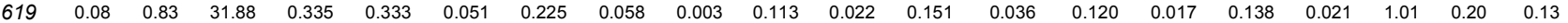

\section{HONDURAS}

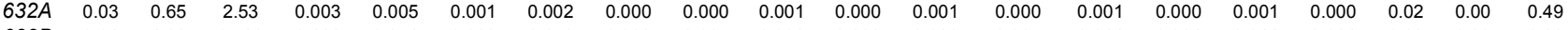

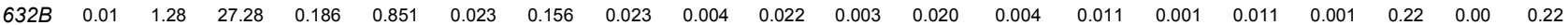




$\begin{array}{llllllllllllllllllllll}633 & 0.00 & 2.61 & 74.37 & 0.012 & 0.005 & 0.002 & 0.008 & 0.002 & 0.003 & 0.004 & 0.001 & 0.007 & 0.002 & 0.007 & 0.001 & 0.008 & 0.001 & 0.34 & 0.02 & 0.02 \\ 634 & 0.00 & 0.62 & 4.40 & 0.059 & 0.120 & 0.014 & 0.055 & 0.012 & 0.001 & 0.010 & 0.001 & 0.010 & 0.002 & 0.006 & 0.001 & 0.008 & 0.001 & 0.06 & 0.03 & 0.68 \\ 635 & 0.01 & 0.41 & 1.62 & 0.016 & 0.038 & 0.004 & 0.017 & 0.004 & 0.000 & 0.004 & 0.000 & 0.006 & 0.001 & 0.004 & 0.000 & 0.005 & 0.001 & 0.03 & 0.01 & 1.11 \\ 787 & 0.11 & 0.02 & 1.64 & 0.020 & 0.042 & 0.004 & 0.017 & 0.002 & 0.000 & 0.004 & 0.000 & 0.005 & 0.001 & 0.004 & 0.000 & 0.006 & 0.001 & 0.01 & 0.00 & 0.67 \\ 791 & 0.09 & 0.01 & 2.11 & 0.017 & 0.016 & 0.003 & 0.012 & 0.002 & 0.000 & 0.002 & 0.000 & 0.004 & 0.000 & 0.002 & 0.000 & 0.003 & 0.000 & 0.00 & 0.00 & 0.35\end{array}$

BRAZIL

$\begin{array}{lllllllllllllllllllll}621 & 0.02 & 0.02 & 0.98 & 15.321 & 12.745 & 3.179 & 12.426 & 2.401 & 0.331 & 2.430 & 0.381 & 2.501 & 0.546 & 1.612 & 0.229 & 1.430 & 0.208 & 0.07 & 0.68 & 40.98\end{array}$

$\begin{array}{lllllllllllllllllllll}622 & 0.01 & 0.57 & 2.29 & 0.086 & 0.123 & 0.023 & 0.082 & 0.017 & 0.002 & 0.014 & 0.002 & 0.014 & 0.002 & 0.007 & 0.001 & 0.021 & 0.001 & 0.04 & 0.10 & 0.15\end{array}$

$\begin{array}{lllllllllllllllllllll}761 & 0.00 & \text { n.d. } & 5.74 & 0.009 & 0.024 & 0.003 & 0.013 & 0.003 & 0.000 & 0.004 & 0.000 & 0.006 & 0.001 & 0.004 & 0.000 & 0.005 & 0.000 & 0.00 & 0.01 & 0.02\end{array}$

$\begin{array}{llllllllllllllllllllll}762 & 0.01 & \text { n.d. } & 21.01 & 0.061 & 0.162 & 0.033 & 0.176 & 0.047 & 0.009 & 0.051 & 0.008 & 0.049 & 0.010 & 0.030 & 0.004 & 0.027 & 0.004 & 0.01 & 0.01 & 0.02\end{array}$

$\begin{array}{lllllllllllllllllllll}763 & 0.02 & \text { n.d. } & 126.92 & 0.585 & 1.339 & 0.183 & 0.834 & 0.208 & 0.057 & 0.262 & 0.045 & 0.319 & 0.073 & 0.233 & 0.036 & 0.255 & 0.039 & 0.06 & 0.31 & 0.88\end{array}$

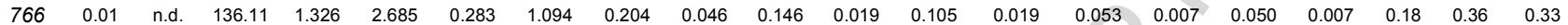

AUSTRALIA

$\begin{array}{lllllllllllllllllllll}827 & 0.07 & 2.15 & 118.66 & 1.796 & 4.213 & 0.442 & 1.705 & 0.333 & 0.097 & 0.266 & 0.042 & 0.256 & 0.051 & 0.154 & 0.023 & 0.193 & 0.024 & 1.68 & 0.86 & 0.25\end{array}$ $\begin{array}{lllllllllllllllllllllll}234 & 0.06 & \text { n.d. } & 182.66 & 2.331 & 4.775 & 0.552 & 2.191 & 0.446 & 0.146 & 0.379 & 0.058 & 0.348 & 0.069 & 0.201 & 0.029 & 0.216 & 0.029 & 2.53 & 1.12 & 0.30\end{array}$ $\begin{array}{llllllllllllllllllllll}234 & 0.05 & \text { n.d. } & 151.02 & 1.039 & 2.135 & 0.246 & 0.991 & 0.199 & 0.061 & 0.172 & 0.026 & 0.163 & 0.033 & 0.098 & 0.014 & 0.117 & 0.014 & 0.94 & 0.59 & 0.17\end{array}$

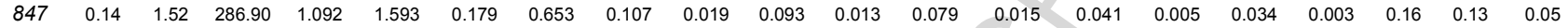

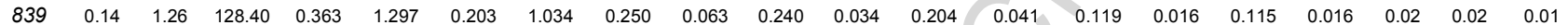

$\begin{array}{llllllllllllllllllllll}832 & 0.22 & 4.21 & 301.49 & 0.824 & 1.524 & 0.151 & 0.608 & 0.110 & 0.019 & 0.109 & 0.015 & 0.094 & 0.019 & 0.053 & 0.007 & 0.057 & 0.005 & 0.03 & 0.10 & 0.03\end{array}$

$\begin{array}{llllllllllllllllllllll}835 & 0.19 & 3.02 & 119.41 & 0.404 & 0.840 & 0.094 & 0.376 & 0.073 & 0.020 & 0.063 & 0.009 & 0.056 & 0.011 & 0.032 & 0.004 & 0.057 & 0.004 & 0.15 & 0.26 & 0.07\end{array}$

$\begin{array}{lllllllllllllllllllll}844 & 0.08 & 1.81 & 143.75 & 1.065 & 2.495 & 0.310 & 1.413 & 0.501 & 0.193 & 0.783 & 0.112 & 0.670 & 0.133 & 0.361 & 0.049 & 0.315 & 0.045 & 1.03 & 0.86 & 0.15\end{array}$

$\begin{array}{llllllllllllllllllllll}818 & 0.00 & 0.00 & 0.03 & 0.001 & 0.004 & 0.001 & 0.001 & 0.000 & 0.000 & 0.000 & 0.000 & 0.000 & 0.000 & 0.000 & 0.000 & 0.000 & 0.000 & 0.02 & 0.00 & 0.06\end{array}$

$\begin{array}{llllllllllllllllllllll}387 \mathrm{C} & 0.00 & 1.30 & 63.83 & 0.632 & 0.916 & 0.090 & 0.343 & 0.073 & 0.011 & 0.091 & 0.016 & 0.111 & 0.024 & 0.071 & 0.010 & 0.075 & 0.010 & 0.49 & 0.48 & 0.28\end{array}$

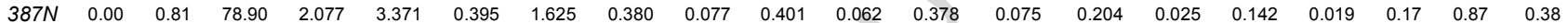

SLOVAKIA

$\begin{array}{lllllllllllllllllllll}204.2 & 0.17 & 11.21 & 32.34 & 0.439 & 1.244 & 0.227 & 1.395 & 0.411 & 0.124 & 0.544 & 0.078 & 0.519 & 0.123 & 0.390 & 0.059 & 0.393 & 0.063 & 0.01 & 0.05 & 0.74\end{array}$

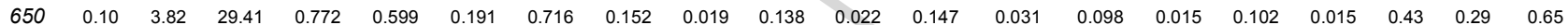

\section{KAZAKHSTAN}

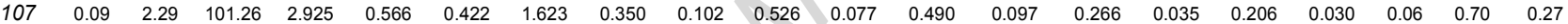
$\begin{array}{llllllllllllllllllllll}652 & 0.06 & 0.12 & 60.80 & 3.298 & 2.417 & 0.706 & 2.518 & 0.478 & 0.113 & 0.364 & 0.050 & 0.273 & 0.050 & 0.137 & 0.019 & 0.117 & 0.017 & 1.21 & 0.63 & 0.26\end{array}$ $\begin{array}{llllllllllllllllllllll}653 & 0.06 & 0.14 & 39.57 & 17.856 & 5.902 & 2.491 & 9.709 & 1.770 & 0.460 & 1.889 & 0.239 & 1.224 & 0.213 & 0.526 & 0.067 & 0.385 & 0.053 & 0.95 & 0.85 & 0.71\end{array}$

TANZANIA

$\begin{array}{lllllllllllllllllllllll}793 & 0.17 & 0.01 & 0.26 & 0.049 & 0.192 & 0.016 & 0.068 & 0.018 & 0.004 & 0.015 & 0.002 & 0.013 & 0.002 & 0.008 & 0.001 & 0.013 & 0.002 & 0.06 & 0.02 & 0.18\end{array}$

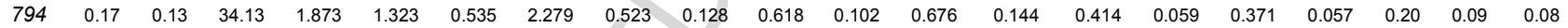

USA

$\begin{array}{llllllllllllllllllllll}795 & 0.20 & 5.27 & 5.25 & 0.635 & 1.468 & 0.186 & 0.747 & 0.238 & 0.002 & 0.357 & 0.078 & 0.584 & 0.131 & 0.450 & 0.088 & 0.736 & 0.128 & 0.04 & 0.13 & 0.11\end{array}$

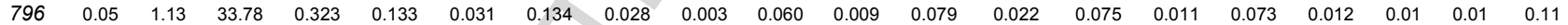

$\begin{array}{lllllllllllllllllllll}797 & 0.05 & 0.33 & 1.34 & 0.016 & 0.039 & 0.003 & 0.014 & 0.005 & 0.000 & 0.012 & 0.003 & 0.026 & 0.006 & 0.022 & 0.003 & 0.029 & 0.004 & 0.20 & 0.18 & 3.67\end{array}$

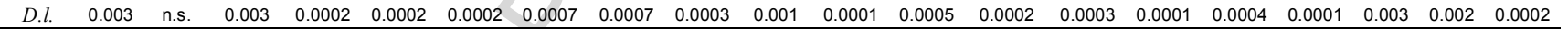



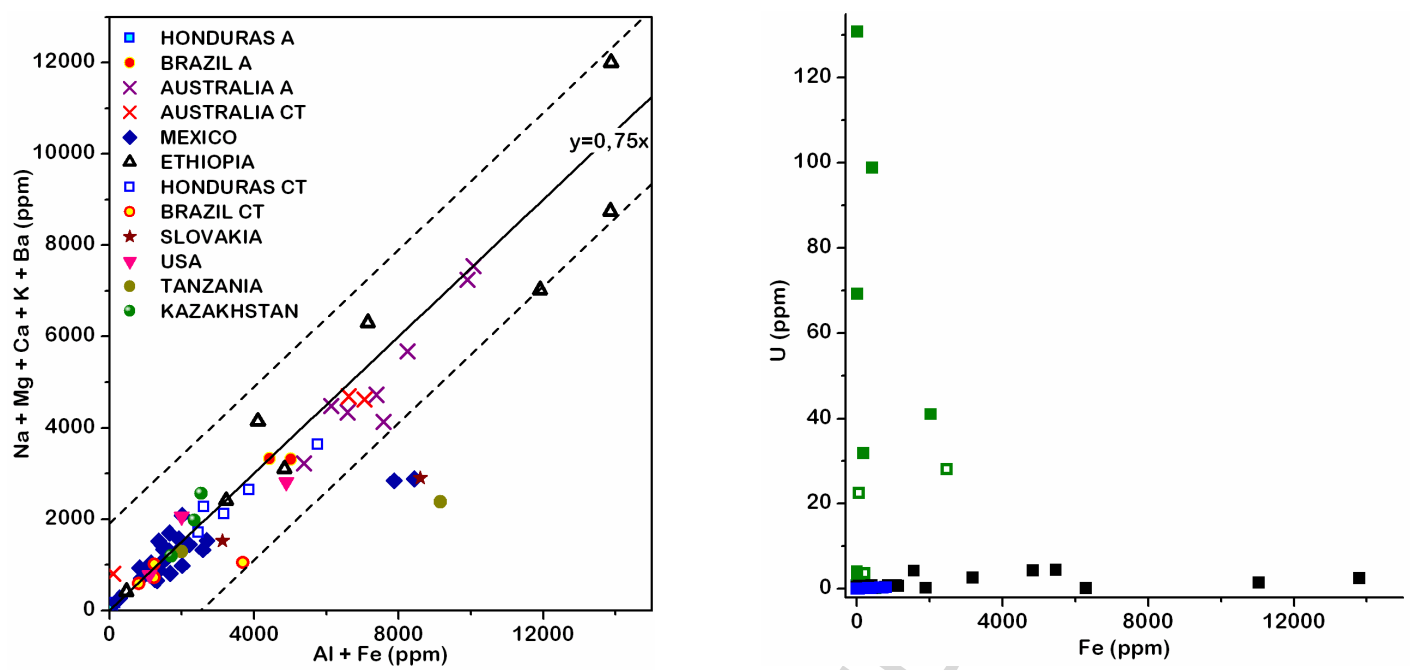

Figure 1: Correlation between the sum of the most Figure 2: Green versus blue luminescence, as a common trivalent ions $(\mathrm{Al}+\mathrm{Fe})$ and monovalent function of $\mathrm{U}$ and $\mathrm{Fe}$ content. Green and blue and divalent ions $(\mathrm{Na}+\mathrm{Mg}+\mathrm{Ca}+\mathrm{Ba}+\mathrm{K})$. It is squares represent respectively intense green and explained by a "pseudo-crystallochemistry" of blue luminescence, whereas empty squares opals. The charge imbalance produced by the represent weak luminescence. Black squares substitution of $\mathrm{Al}$ and $\mathrm{Fe}$ for $\mathrm{Si}$ is compensated by represent inert opals. The more $\mathrm{Fe}$ an opal some monovalent and divalent ions. A small contains, the less it luminescences. The green number of opals do not follow perfectly this rule, luminescence is correlated with $U$ content. Blue but are nevertheless close to the general trend. luminescence occurs when $\mathrm{U}<1 \mathrm{ppm}$ and $\mathrm{Fe}<$ $1000 \mathrm{ppm}$.

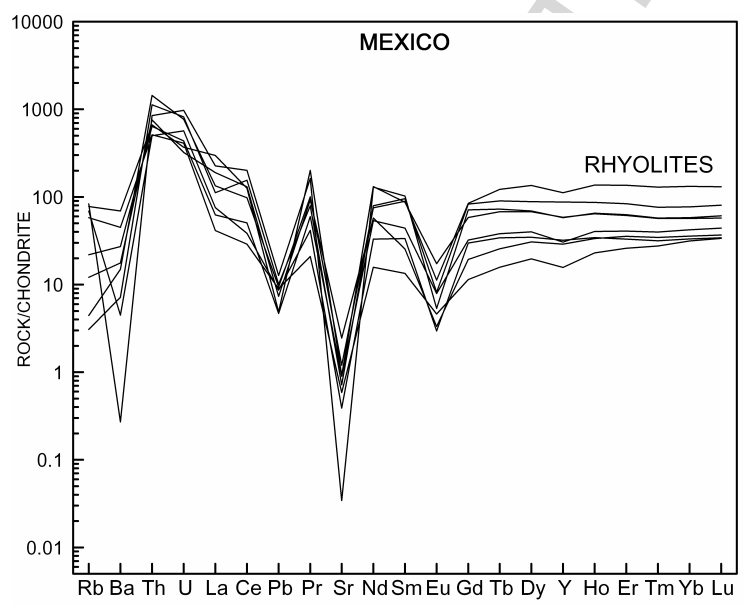

Figure 3: Multi-element diagram of Mexican opal's host rocks normalized to chondrite. They have a typical pattern for rhyolites, with $\mathrm{Ba}, \mathrm{Sr}$ and Eu negative anomalies.

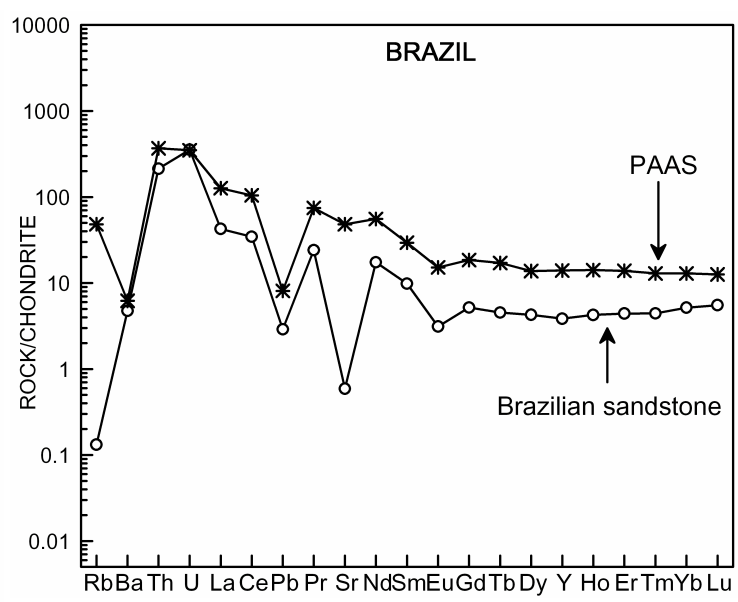

Figure 4: Multi-element diagram of Brazilian opal's host rock and PAAS (Taylor and McLennan, 1983) normalized to chondrite. Brazilian sandstone and PAAS are near parallel, which means that the sandstone is a typical sedimentary rock. 

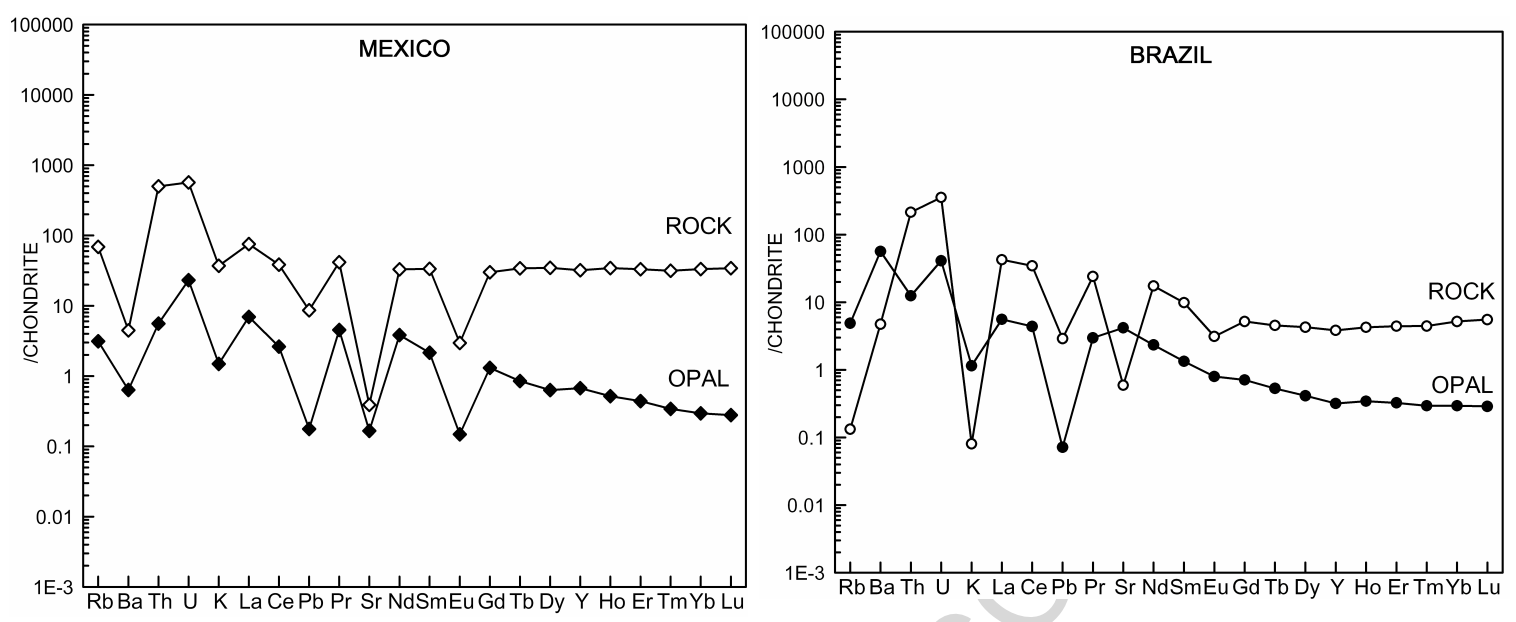

Figure 5: Multi-element diagram of a Mexican Figure 6: Multi-element diagram of a Brazilian opal compared to its rhyolitic host rock opal compared to its sandstone host rock normalized to chondrite (couple $\mathrm{n}^{\circ} 765$ ). The two normalized to chondrite (couple $\mathrm{n}^{\circ} 766$ ). The two patterns are near parallel, with always a lesser patterns are near parallel, except for $\mathrm{Rb}, \mathrm{Ba}, \mathrm{K}, \mathrm{Sr}$, element concentration in opal compared to its host which are more concentrated in opal. Depletion in rock. The depletion in HREE compared to LREE HREE compared to LREE is explained by a lesser $(\mathrm{La} / \mathrm{Yb}$ greater in opal than in rhyolite) is mobility of HREE, which stay preferentially in the explained by a lesser mobility of HREE, which rock during weathering.

stay preferentially in the rock during weathering.
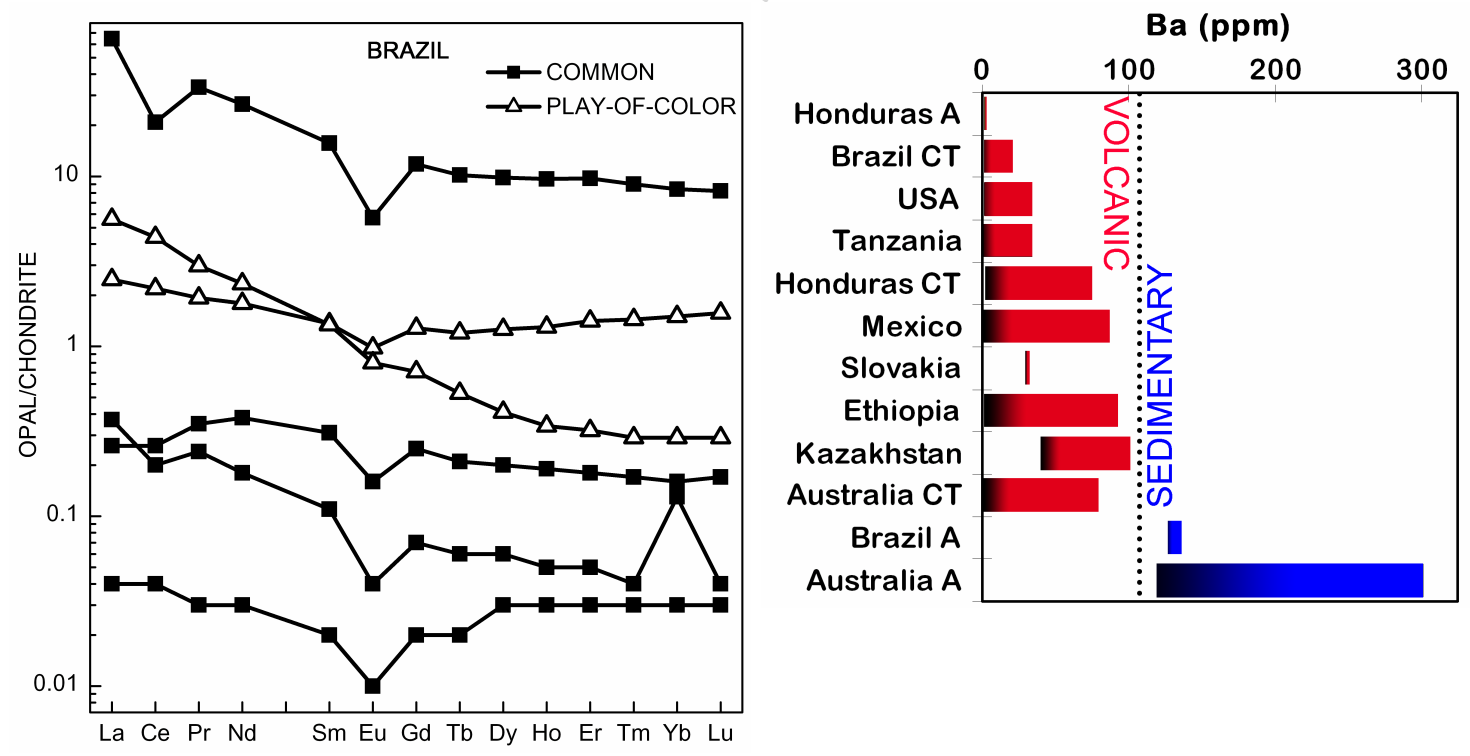

Figure 7: REE distribution patterns for play-of- Figure 8: The Ba content of opal can help separate color and common opals from Brazil. Play-of- volcanic $(<110 \mathrm{ppm})$ from sedimentary $(>110$ color opals are restricted to a narrower range of ppm) gem opals.

REE content variations than common opals. 

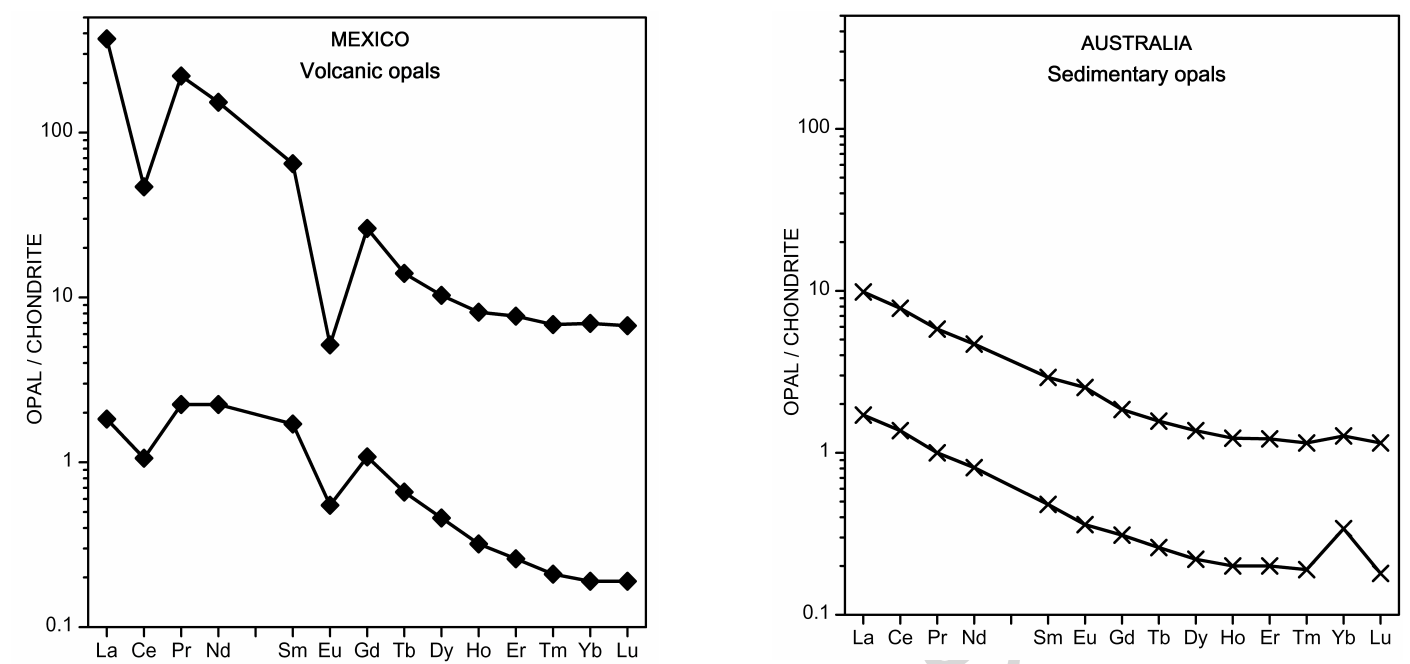

Figure 9: Chondrite-normalized REE distribution patterns of opals of volcanic and sedimentary origin, represented by examples from Mexico and Australia respectively. They both present a depletion from HREE to LREE. a- The range of patterns for Mexican opals, which always have a negative Eu anomaly and often a negative Ce anomaly. b- The range of patterns for Australian opals, which have little to no $\mathrm{Eu}$ and $\mathrm{Ce}$ anomalies.

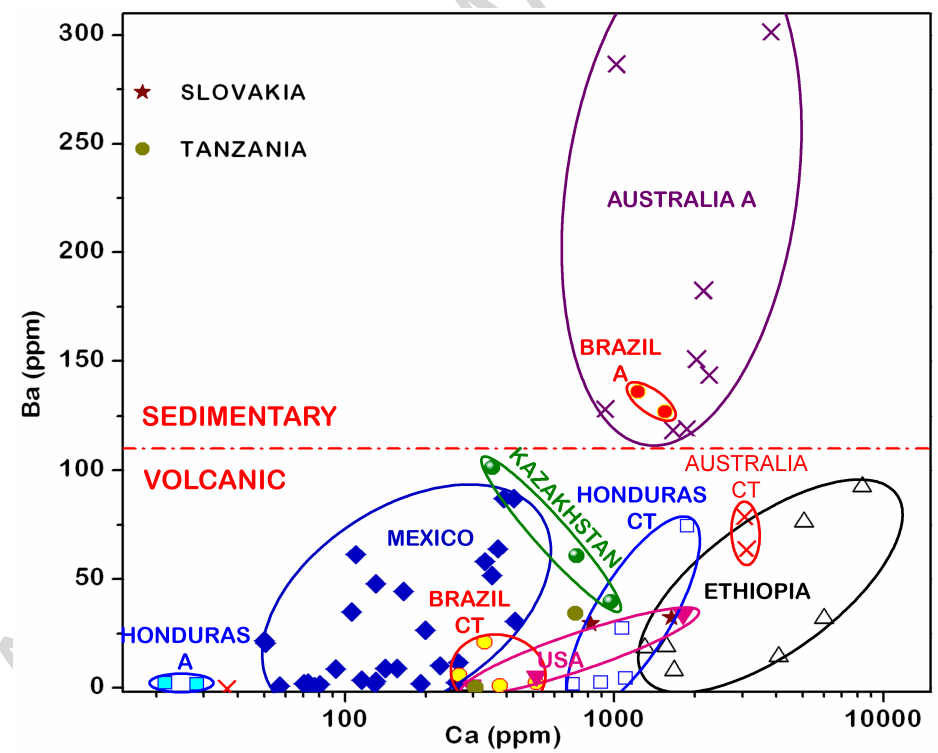

Figure 10: Ba versus Ca diagram to identify an opal geographic origin. Ellipsoids represent a visual guide for the dispersion of points for each opal-producing region.

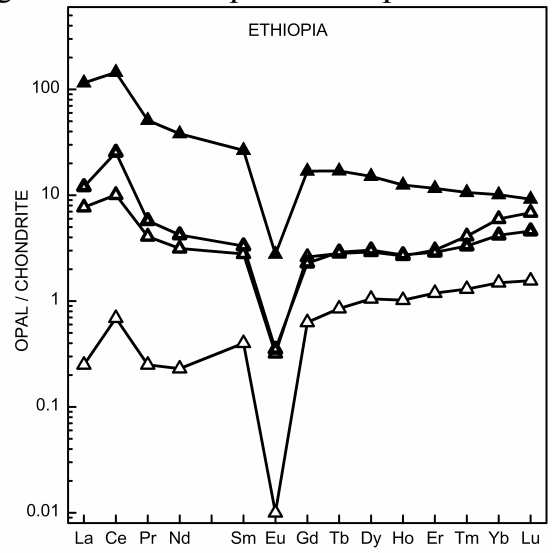

Figure 11: Chondrite-normalized REE distribution patterns of opals from different geographic origins.

a- Ethiopia: typical depletion from LREE to HREE, Eu negative anomaly and generally a positive Ce anomaly (one sample not), helpful to distinguish them from other opals. 


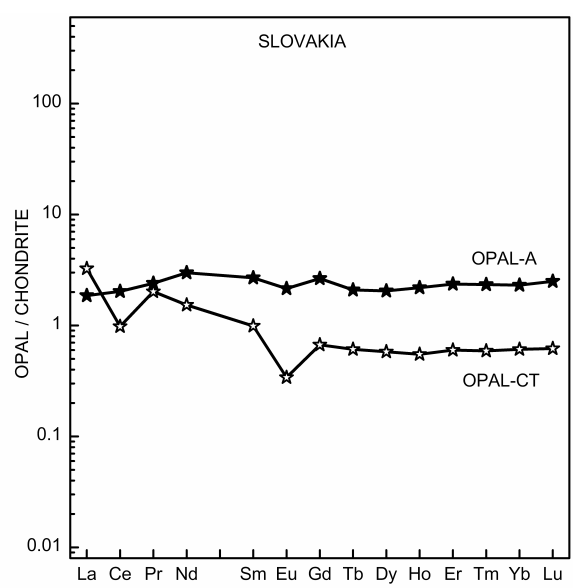

b- Slovakia: almost flat shape, only a small negative Eu anomaly.
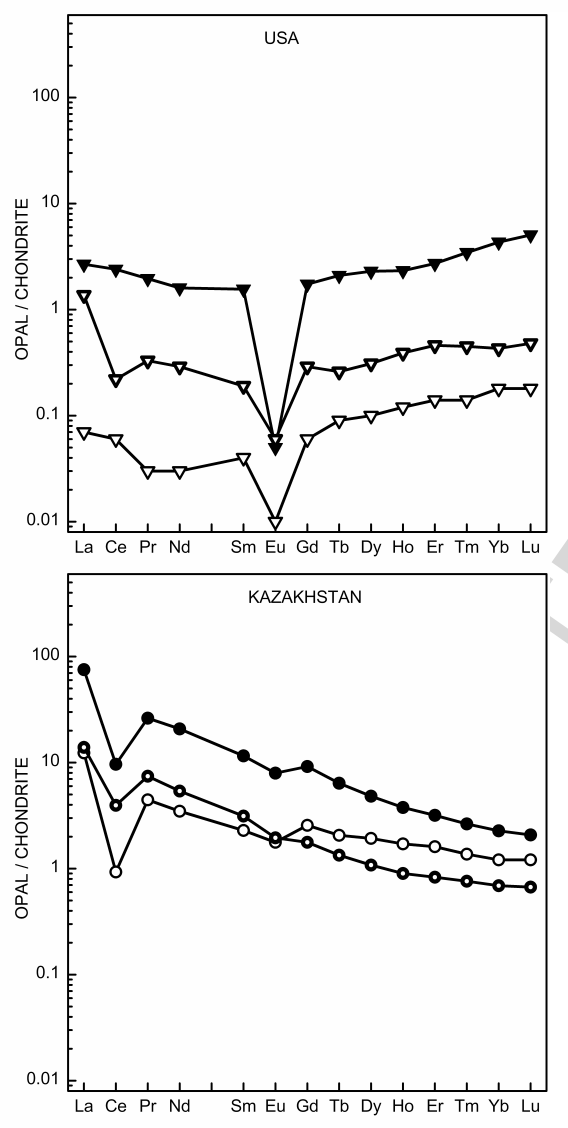

d- Kazakhstan: typical depletion from LREE to HREE; small negative anomaly in $\mathrm{Eu}$, less intense than that in Ce.

e- Los Laureles mine, Jalisco, Mexico: this deposit is the only one which can be differentiated from other Mexican deposits, with its REE patterns in flat inverse " $U$ "; the intense negative anomaly in $\mathrm{Eu}$ is present, as in other Mexican deposits. 